\title{
Are There Treatment Duration Differences in the Seattle and Denver Income Maintenance Experiments?
}

\author{
by \\ Melvin Stephens Jr. \\ Carnegie Mellon University \\ and \\ National Bureau of Economic Research
}

September 2007

Address. H. John Heinz III School of Public Policy and Management, Carnegie Mellon University, 5000 Forbes Avenue, Pittsburgh, PA 15213. E-mail: mstep@cmu.edu

This project was supported, in part, by the Carnegie Mellon Berkman Faculty Development Fund. I would like to thank to Kerwin Charles, Steve Haider, and participants at the 2005 Institute for Research on Poverty Summer Research Workshop for helpful comments and suggestions. I am especially grateful to Phil Robins for extremely beneficial discussions and the provision of SIME/DIME research memorandums. Erin Krupka provided outstanding research assistance. 


\title{
Are There Treatment Duration Differences in the Seattle and Denver Income Maintenance Experiments?
}

\begin{abstract}
This paper re-examines the labor supply responses in the Seattle and Denver Income Maintenance Experiments (SIME/DIME). Specifically, the original experimental results show a significantly larger labor supply response for men and women from dual-headed households in the five-year Negative Income Tax (NIT) treatment relative to those in the three-year NIT treatment. Although typically thought of only as an NIT experiment, the SIME/DIME also included a job training experiment that enrolled roughly 60 percent of households, including both NIT treatment and control households. The original empirical specification imposed strong assumptions on the treatment response to the job training experiment in order to increase the precision of the estimated parameters. Once these assumptions are relaxed, the labor supply differences between men in the threeand five-year NIT treatments fall by over 50 percent in magnitude and become statistically insignificant. The analogous differences for women are almost entirely explained by these specification changes. Whereas the original findings of the SIME/DIME were inconsistent with the standard life-cycle labor supply model, the results of the re-analysis are mostly consistent with the model.
\end{abstract}

JEL Classification. I38, J22 


\section{Introduction}

The Seattle and Denver Income Maintenance Experiments (SIME/DIME) began in the early 1970s as the last of the four major evaluations of the proposed Negative Income Tax (NIT). ${ }^{1}$ The impetus behind implementing an NIT was two-fold. First, the growing size of welfare programs such as Aid to Families with Dependent Children and Food Stamps led to concerns that the existing income maintenance system was inefficient. Second, analysts worried that the high tax rates on earned income, especially when combined across programs, would greatly reduce labor supply and not provide the proper incentives for households to subsequently become independent of the programs. Not only did the experiments allow the theorized impacts of a negative income tax to be quantified, the data produced by these experiments led to the development of a number of influential econometric methodologies for a variety of important topics such as analyzing the impact of taxation on labor supply (Burtless and Hausman 1978) and correcting for the effect of sample attrition in panel data (Hausman and Wise 1977).

The SIME/DIME differed from prior NIT experiments along a number of dimensions. First, while all of the NIT experiments used various combinations of grant levels (i.e., benefit levels for households that do not work) and tax rates on earned income (i.e., the amount by which the grant is reduced for each dollar earned), the SIME/DIME enrolled a larger number of participants than all of the previous NIT experiments combined. In addition, whereas the previous NIT experiments were limited to three years in length, the SIME/DIME included treatment durations of both three and five years. ${ }^{2}$ Since the experiments would be temporary, there was a concern that the resulting labor supply estimates would not correctly identify the impact of a permanently implemented NIT (Metcalf 1973). Thus, the varying program lengths in the SIME/DIME were initiated to

\footnotetext{
1 Prior to the SIME/DIME, the other NIT experiments were the New Jersey Experiment, the Rural Experiment (conducted in Iowa and North Carolina), and the Gary, Indiana Experiment. See Spiegelman and Yaeger (1980) for a discussion of the history of the NIT and the SIME/DIME.

2 After the first two years of the SIME/DIME, a small number of households were shifted from either control status or the three-year treatment into a twenty-year treatment. However, data collection for these households ended when the interviewing for the three- and five-year duration households was completed. The twenty-year treatment was officially ended after six years (Robins 1984).
} 
help identify the parameters necessary to estimate the long-run impact of a permanent NIT (Keeley et al. 1978; Burtless and Greenberg 1982). Finally, the SIME/DIME also included a randomized job training component while only one of the other experiments added a non-NIT treatment. ${ }^{3}$

Figure 1a presents the estimated experimental impact of the NIT for males in dualheaded households that is reported in the Final Report of the Seattle and Denver Income Maintenance Experiments (United States Department of Health and Human Services 1983). ${ }^{4}$ Once households have fully adjusted to the experiment by the second year, average hours of work are significantly reduced by 133 hours annually for the three-year experimentals and by 228 hours for the five-year treatments. The impact remains essentially constant throughout the remainder of the experimental period for both treatment duration groups. T-tests for the equality of the impact across duration groups reject the null hypothesis for each of the first three experimental years. The larger impact of the five-year treatment is consistent with a significantly larger (life-cycle) wealth effect for households assigned to the longer program duration. Similar differences are found for women in dual-headed households while there are no treatment duration differences for women in single-headed households. Since none of the other NIT experiments varied the length of the treatment duration, these findings represent the only experimental evidence regarding the importance of wealth effects in life-cycle labor supply decisions.

While the SIME/DIME is primarily thought of as a negative income tax experiment, it was, in fact, comprised of two major experimental components: an NIT treatment and a job training treatment. The Final Report notes that "[s]ince SIME/DIME essentially consists of two experiments conducted simultaneously, a family may be an experimental in one treatment and a control in the other" (United States Department of Health and Human Services 1983, p. 26). Thus, households could be assigned to treatment status for both experiments, to control status for both experiments, or they might serve as a control

\footnotetext{
3 The Gary Experiment included a randomized child care subsidy component.

4 The point estimates and standard errors for Figure 1a are presented in Panel A of Table 4 and have been taken from Table 3.4 on p.120 of the Final Report. For expositional ease, the t-statistics for the difference between the three- and five-year treatment effects shown in the Table are converted from F-statistics that are presented in the Final Report.
} 
for one experiment while simultaneously being assigned to treatment status in the other experiment. Of the original 4,800 SIME/DIME families, 57 percent were assigned to an NIT treatment while 59 percent were assigned to a job training treatment. As the above quote makes clear, however, some of the NIT control households were in fact enrolled in the job training treatment. While 21 percent of the overall sample fell into this category, these households comprised 49 percent of the NIT control group.

Although previous papers have examined the differential response to the SIME/DIME by the NIT treatment duration, many of these same studies overlooked the possibility that the response to the concurrent job training experiment may have differed by treatment duration. The empirical specifications used in the Final Report (United States Department of Health and Human Services 1983) as well as in the other papers that examined treatment duration differences included a set of regressors for the job training experiment but did not allow the effect of job training on labor supply to differ between those enrolled in the three- and five-year program durations. ${ }^{5}$ If the impact of the job training experiment on work effort varied by the length of time the household was assigned to the treatment, then the failure to control for the program duration of this experiment may result in an omitted variables bias. In addition, the specification assumes that each of the two treatments has an additive effect on labor supply. If there are time allocation interactions for households receiving both treatments due to the substitution patterns between work hours, time spent in training, and leisure time, this additivity assumption may generate a specification bias. Either of these two specification errors may lead to biased inferences.

For an omitted variables bias to exist, two conditions must be met in the textbook scenario. To satisfy the first condition for an omitted variables bias, that the omitted variable is correlated with the included regressor, the NIT and the job training assignments must be correlated. Rather than using a simple random assignment procedure, the SIME/DIME used the Conlisk-Watts assignment model to determine the optimal distribution of households to treatment status in order to minimize the variance of the estimated effects for a given budget. Most notably, this assignment mechanism randomly assigns

5 E.g., see Keeley et al. (1978), Robins and West (1980), and Burtless and Greenberg (1982) 
households to treatment status within cells defined by income class, race, site (Seattle or Denver), and family type (single- or dual-headed households). Such an assignment requires estimation to condition on these assignment variables which is done in all studies that analyze the SIME/DIME. Less notable, but equally as important, is that the assignment model determined a probability of assignment to each combination of NIT treatment/job training treatment (including the no treatment states). Therefore, while assignment to each treatment combination is randomly determined within each cell, the probability of being assigned as a job training treatment is not necessarily independent of NIT treatment status. 6

To see the correlation across SIME/DIME treatment status, Table 1 presents the joint distribution of NIT and job training treatment assignments by program duration. For households in the three-year program, 60\% are assigned to the NIT treatment while $63 \%$ are assigned to the job training treatment. However, the probability of assignment to the job training treatment within NIT treatment status is not constant. Fifty-five percent (725/1307) of NIT controls are assigned to a job training treatment while $68 \%(1322 / 1932)$ of NIT experimental households are assigned to a job training treatment. The probability of being assigned as a job training treatment in the five-year program for NIT controls and treatments is $39 \%$ and $59 \%$, respectively. Thus, assignment to job training status is not independent of the household's NIT treatment assignment.

The second condition for an omitted variables bias requires the coefficient on the omitted variable to be non-zero in the equation of interest. Since the empirical specification used in previous studies controls for job training treatment assignment, but does not allow for differential job training effects by treatment duration, satisfying this condition requires the effect of job training on labor supply to differ between the three-year and five-year program durations. Table 2 presents the impact of the job training treatments on labor supply for men in dual-headed households that is calculated as part of the re-analysis presented

\footnotetext{
6 As an example, suppose that the assignment model determines that the optimal assignment for households is to have $20 \%$ assigned to no treatment at all, $20 \%$ assigned to the job training treatment only, $20 \%$ assigned to the NIT treatment only, and $40 \%$ assigned to both treatments. Although households are randomly assigned to one of these four treatment groups, among the $40 \%$ of the sample that are NIT controls, one-half of the observations will receive the job training treatment. However, two-thirds of the $60 \%$ of the sample that are NIT treatments will receive the job training treatment.
} 
in this paper. The job training experiment contained three treatments: a counseling only treatment, a counseling plus a 50 percent subsidy for educational expenses treatment, and a counseling plus a 100 percent educational expenses subsidy treatment although the third treatment was not offered to households enrolled in the five-year program. The rows of the Table show the response to the job training treatments by treatment duration. As can be seen in the Table, especially for the second treatment, the impact of the job training experiment on hours worked is larger in magnitude in the five-year program than in the three-year program. In the second and third years of the program, the program duration differences for the job training treatment are roughly as large as the differences for the NIT treatment. The program duration difference is only significant during the second experimental year for the second job training experiment. The evidence of this second omitted variables bias condition for women in dual-headed households is somewhat stronger with the magnitude of the job training program duration differences, shown in Table 3, both being larger than the NIT program duration differences (shown below) and, for the second job training treatment, being statistically significant in the first experimental year and marginally significant in the second year. Since the first condition for an omitted variables bias is met due to the experimental design and the data satisfy the second condition in some years while being suggestive of the condition in other years, failure to control for the differential response to the job training experiment by program duration may impart a bias on the estimated effects of the NIT on labor supply.

A second potential specification error with the Final Report analysis is the assumption that the job training and NIT treatments have an additive effect on labor supply decisions. The job training education subsidy lowers the price of time spent in training while the NIT wage tax reduces the price of time either spent in training or in pure leisure. While each of these experimental price changes induces households to substitute away from working, the labor supply response to these changes is not required to be linear. If it is not, then the response for households enrolled in both treatments may not equal the sum of the responses for households participating in each of the two individual experiments. Therefore, the reanalysis examines the impact on the results when allowing the treatment response to differ across households enrolled in a single experiment and those enrolled in both treatments. ${ }^{7}$

7 The importance of this additivity assumption on the estimated parameters in the SIME/DIME has 
This paper presents a re-analysis of the labor supply effects of the Seattle and Denver Income Maintenance Experiments. The estimates found in the Final Report indicate that labor supply exhibits a significantly larger response in the five-year NIT experiment than in the three-year NIT experiment for both men and women in dual-headed households. However, when the labor supply effect of the job training treatment is allowed to differ by the duration of the job training treatment, these NIT duration differences become statistically insignificant and, for women, the point estimates for both treatment durations are almost identical. When the additivity assumption for the treatment effects is relaxed, the results continue to indicate that there are no treatment duration differences for women. The results for men are mixed. While there are no treatment duration differences for men enrolled in both experiments, there are significant differences for men enrolled only in the NIT. However, when comparing between those enrolled only in a single experiment and those enrolled in both experiments, the findings indicate that the additivity assumption is incorrect. Taken as a whole, the results suggest that failure to control for the household's NIT and job training treatment assignments by program duration as well as interactions between the two treatments may result in a serious specification error. ${ }^{8}$

These findings have two important implications. First, the original findings in the Final Report are inconsistent with the standard life-cycle labor supply model (Ashenfelter 1984; Browning, Deaton, and Irish 1985). This interpretation is based, however, on biased NIT treatment estimates. As is discussed below, the new findings are mostly consistent with the life-cycle model. Second, a recent large literature has extensively examined program evaluation methodologies and potential problems with these approaches. ${ }^{9}$ Even

been noted in another context. Findings presented in the Final Report show that the NIT experiment sharply increased marital instability (United States Department of Health and Human Services 1983). Cain and Wissoker (1990a) present results from specifications in which they allow the marital instability response to vary between the NIT only treatment, the job training only treatment, and the combined NIT/job training treatment. They find significant effects on marital stability only for the combined NIT/job training treatment and argue that the "pure" NIT does not have an effect on marital dissolution. For additional discussion see Hannan and Tuma (1990) and Cain and Wissoker (1990b).

8 Some studies that use the SIME/DIME only for the panel data aspect limit their sample to the "control" observations only. However, a control observation is typically defined as an NIT control. By ignoring the fact that roughly half of the NIT controls are enrolled in the job training experiment, these studies also may have produced biased estimates.

9 See Heckman, LaLonde, and Smith (1999) for an extensive review. 
when the estimation method properly accounts for the assignment procedure, issues such as individuals randomized for treatment leaving the study (dropout bias) and individuals randomized out of treatment gaining entrance to substitute programs from alternative service providers (substitution bias) may affect the estimated results (Heckman et al. 2000). In the current paper, the failure to fully account for the assignment procedure in the empirical specification imparts a bias on the estimated program effects. The findings here demonstrate that complicated assignment methodologies can result in crucial interactions among treatment assignments that need to be carefully accounted for, perhaps more so than has been previously recognized, when evaluating program impacts.

The rest of the paper is set out as follows. The next section discusses the set-up and implementation of the SIME/DIME experiments and is followed by a section that briefly discusses the data used in the re-analysis. Section four presents the re-analysis of the SIME/DIME data. The final section discusses the implications of the re-analysis for models of life-cycle labor supply.

\section{The Seattle and Denver Income Maintenance Experiment}

The Seattle and Denver Income Maintenance Experiments began in 1970 with the enrollment of households in Seattle. ${ }^{10}$ The enrollment of households in Denver was started in the following year after high levels of unemployment in Seattle led to a decision to extend the experiment to an additional city. Since the possible expansion of the NIT to a national setting would include dual-headed as well as single-headed households, both types of households were included in the experiment. The Seattle experiment was comprised of Black and White families while the Denver experiment also included Latino families.

The SIME/DIME consisted of a number of experimental treatments. Three different grant levels $(\$ 3800, \$ 4600$, and $\$ 5600)$ and four different marginal tax rates $(50 \%, 70 \%$, a declining $70 \%$, a declining $80 \%$ ) were used to generate eleven experimental grant level-tax

10 Most of the discussion in this section is taken from the United States Department of Health and Human Services $(1983,1985)$. 
rate combinations. ${ }^{11}$ In addition, households were exposed to a job training treatment. Households selected for job training could either be given counseling on the benefits of undertaking job training, counseling plus a 50 percent subsidy for direct costs of any job training that was undertaken, or counseling plus a 100 percent subsidy.

Assignment to experimental treatment status in the SIME/DIME relied on the ConliskWatts assignment model (as opposed to pure random assignment) which minimizes the variance of the estimated parameters for a given budget amount (Conlisk 1972). ${ }^{12}$ The assignment model was run separately for each race-family type (single- or dual-headed)program duration combination to determine the optimal number of observations for each treatment and control group within each of the normal income categories for a single site. ${ }^{13}$ Thus, the probability of assignment to treatment depends upon race, family type, and normal income. According to the Final Report, "[a]ll families who had the same [normal] income class, race, and family type constituted a group. The assignment model then specified the number from each group to be enrolled in each of the experimental treatments and control group. A random draw from within each group then determined

11 The grant dollar levels are as of the beginning of the experiment and were adjusted by each city's CPI in order to maintain the real amounts. The grant amounts were adjusted for family size with the amounts listed in the text being for a family of four. For the declining marginal tax rates, households were taxed at the initial rate for the first $\$ 1000$ of earned income, at a rate 5 percent lower for the next $\$ 1000$ of earned income, and declining by $5 \%$ for each $\$ 1000$ thereafter until reaching the breakeven level. All of the grant level-tax rate combinations were used except for the interaction of the declining 70 percent tax rate with the $\$ 5600$ grant level.

12 The idea behind this model is that a more efficient allocation of resources can be achieved by taking into account the costs of various treatments and any expected cost differences across households. An illustration of the Conlisk-Watts model in the single treatment case (and with a fixed budget) is given by Keeley and Robins (1980). If the costs of treatment and control group observations are the same, then the variance of the difference in the average outcomes between the two groups is minimized by assigning equal numbers of observations to each group. However, if the costs of observations differ between groups (which occurs in an NIT since treatments are given payments whereas controls are not), then the optimal ratio of the treatment to control observations to minimize the variance of the differences is inversely related to the ratio of their respective costs.

13 These categories were chosen for a number of reasons. In the SIME/DIME, costs were expected to vary by pre-experimental "normal" income and therefore the household's level of normal income (divided into six categories) was used in the assignment model. The designers of the SIME/DIME also believed that treatment response would vary over other dimensions such as race (Conlisk and Kurz 1972). In addition, it was decided that it was important to examine programs of differing durations in order to extrapolate the results from a limited duration experiment to a permanent national program and to understand the impact of the NIT separately for single- and dual-headed households since the national program may have been extended to the latter set of households. The allocations determined by the assignment model were applied identically to both sites. 
which families would be enrolled and to which treatments" (United States Department of Health and Human Services 1983, p.61). Thus, all empirical specifications need to control for these characteristics in order to consistently estimate the treatment effects.

After screening over 90,000 households, approximately 5,900 households were assigned for enrollment and over 4,800 were actually enrolled. Table 1 presents the distributions of households by treatment status and program duration. ${ }^{14}$ Of the households assigned to the three-year program duration, over eighty percent were assigned to at least one treatment while over forty percent were assigned to both treatments. Moreover, among households assigned to a given treatment (NIT or job training), two-thirds of these households were assigned to both treatments. Among households assigned to the five-year treatment, seventy percent were assigned to at least one treatment and roughly thirty percent were assigned to both treatments. Thus, the share of households assigned to multiple treatments within a program duration comprises a substantial share of those households assigned to treatment status.

Enrollment of over 2,000 households began in Seattle in October 1970 and continued through November 1971. In Denver, over 2,700 households were enrolled starting in October 1971 and lasting through August 1972. Treatment and control observations in the three-year program duration were interviewed for at least four years. Half of those enrolled in the three-year program duration were also given a follow-up survey to gather information in the fifth year following enrollment. Households assigned to the five-year program were interviewed for up to six years. Households that split due to events such as divorce were followed as separate households as were households that became established when kids of the original households moved out.

Households in the SIME/DIME sample were given a periodic interview approximately once every four to five months until they were disenrolled from the experiment. These interviews collected information on each household member's employment history, government benefits received, expenses (such as child care and alimony), and subsidized housing information. In addition, each of the treated families was required to file an income and

14 While the original SIME/DIME enrolled sample included 4,802 households, the program duration and treatment status was determined for 4,793 households in the re-analysis. 
expense report form (IRF) at the end of each month listing all income receipt plus some expenses (e.g., child support and alimony). ${ }^{15}$

\section{The Data}

This paper makes use of the Work Impact files contained in the Seattle and Denver Income Maintenance Experiment data that is available from the National Archives (United States Health and Human Services Department 1985). ${ }^{16}$ These files contain one observation for each of the original household heads from the single and dual-headed households. Variables from the original monthly Labor Supply files such as work effort and wages are contained as six-month aggregates on the Work Impact files. The data are further aggregated to annual measures for the current study to match the observation periods used in the Final Report as well as in a number of other studies. For each observation, the data span the year prior to enrollment as well as up to six years following enrollment. The files also contain information on household demographics, assignment variables, and treatment status along with some wealth and asset information.

To match the results produced in the Final Report, the following set of sample restrictions is imposed. The sample is limited to households that have non-missing data for the demographic variables found in the basic labor supply specification used in the report. In addition, observations for the first four experimental years are restricted to those individuals that are present in all four of these years. Observations used to analyze the fifth experimental year must be present for the first five years and observations used for year six must be present for all six years. After imposing these restrictions on the males in dualheaded households, there are 1923 observations for the first four years, 1256 for year five, and 661 for year six. The analogous numbers from the Final Report are 1911, 1243, and

15 A random sample of control households in Denver also filled out IRFs.

16 It is not clear if the Work Impact files were used in the original analysis of the SIME/DIME. However, as will be shown below, the estimates produced using these data are virtually the same as those appearing in the Final Report when using the same specification. In addition, the Work Impact files have been used in prior studies examining non-experimental outcomes (e.g., Abowd and Card 1989). 
647, respectively. ${ }^{17}$ Thus, the sample sizes used in the re-analysis are very similar to those found in the Final Report and any differences between the data used in the Final Report and the data used for this paper are likely not the reason for any differences between the prior findings and those presented here. ${ }^{18}$

In order to reduce the quantity of results presented here, the primary focus of this paper is the original male and female heads (i.e., those present at the household's enrollment date) of dual-headed households since treatment duration differences exist for these individuals in the Final Report. A brief discussion of the results for original female heads in singleheaded households is also provided although there are no treatment duration differences for this group of individuals.

\section{Re-Analysis of the SIME/DIME}

To better understand how the specification errors affected the original analysis of the SIME/DIME, it is useful to first examine the specification used in the Final Report. The findings in the Final Report were generated from a series of separate cross-sectional regressions for each experimental year. The cross-sectional specification used in the report is

$$
\begin{aligned}
H_{i t}-H_{i p} & =\alpha+\beta A_{i}+\gamma X_{i} \\
& +\delta_{N I T, 3 Y R} T_{N I T, 3 Y R, i}+\delta_{N I T, 5 Y R} T_{N I T, 5 Y R, i} \\
& +\sum_{j=1}^{3} \psi_{J T, j} T_{J T, j, i}+\epsilon_{i t}
\end{aligned}
$$

The dependent variable, $H_{i t}-H_{i p}$, is the difference between experimental year hours of

17 For women in dual-headed households, the sample used here has 2074, 1373, and 726 observations while the Final Report has 2043, 1347, and 705 observations. For women in single-headed households, the current sample has 1433, 945, and 458 observations and the Final Report numbers are 1459, 951, and 458 observations.

18 There was some degree of sample attrition from the SIME/DIME. Robins and West (1986) examine multiple methods for adjusting the analysis for sample attrition and conclude that "attrition bias is not a serious enough problem in the SIME/DIME data to warrant extensive correction procedures" (p. 337). Nevertheless, in results not shown here, a correction for sample attrition developed by Wooldridge (2002, p.585-590) is implemented that is based on the assumption of selection on observables. This correction has no appreciable effect on the results presented here. 
work and pre-experimental work hours. ${ }^{19}$ The set of regressors includes indicators for the assignment variables, $A_{i}$, which includes the normal income categories, race (White, Black, and Latino), and site (Denver and Seattle). ${ }^{20}$ An indicator for being an IRF control is also included among the assignment variables. The household demographic information at the time of enrollment, $X_{i}$, that is used in the Final Report specifications is the age of the individual, the number of family members, and the number of children under five years of age. Also, hours of work and AFDC benefits in the pre-experimental year are included among the $X_{i}{ }^{21}$

The treatment effects are represented by a number of treatment assignment variables in the Final Report specification. The two indicators for the NIT treatment, $T_{N I T, 3 Y R, i}$ and $T_{N I T, 5 Y R, i}$ allow for differential effects of the three-year and five-year NIT treatments on labor supply. The corresponding estimated experimental effects, $\delta_{N I T, 3 Y R}$ and $\delta_{N I T, 5 Y R}$ are the main results presented in the Final Report as well in the Tables and Figures in the current paper. The three job training treatments (counseling only, counseling plus $50 \%$ subsidy, and counseling plus $100 \%$ subsidy) are represented by three indicators in the Final Report specification $T_{J T, 1, i}, T_{J T, 2, i}$, and $T_{J T, 3, i}$.

The Final Report specification shown in equation (1) relies on a number of important assumptions. The first assumption is that the work effort of the households that are assigned to be controls for both treatments does not depend upon whether they serve as controls for the three-year or the five-year program duration. If this assumption is correct, pooling these two sets of households will lead to more efficient estimates. However, a more flexible specification would include an indicator for being enrolled in the five-year program.

19 Applying OLS to equation (1) as is done in the Final Report ignores the fact that individuals who choose not to work are at a corner solution. Although failing to account for the non-interior solution biases the parameter estimates, the re-analysis does not specifically address this issue. However, in results not shown here, changing the dependent variable to be current year hours of work, $H_{i t}$, and then applying a Tobit model still yields significant differences between the three- and five-year program durations. The need to adjust for the differential impact of job training program duration is still important when using this alternative specification.

20 Family type is not controlled for in the regressions since the analysis is performed separately for men in dual-headed households, women in dual-headed households, and women in single-headed households.

21 Pre-experimental hours are included in (1) to match the Final Report specification. The findings are hardly changed when this regressor is excluded from the analysis. 
The second assumption, which is the one of the two focuses of the re-analysis, is that the labor supply impact of the three-year job training treatment is the same as the fiveyear job training treatment. However, the findings in Tables 2 and 3 indicate that job training has a much larger, although not always statistically significant, impact on the work effort of households in the five-year program relative to those in the three-year program. ${ }^{22}$ In addition, Table 1 shows that while roughly one-third of job training treatments are assigned to the counseling plus $50 \%$ subsidy in the three-year program, more than one-half of job training experimentals in the five-year program are enrolled in this treatment. This distinction among job training programs is important to note since the largest labor supply differences between the three- and five-year durations due to the job training program are found for this particular treatment. ${ }^{23}$

The impact of excluding a set of regressors for the differential effect of the five-year job training program is perhaps easiest to examine in the context of the textbook omitted variables bias scenario. The two conditions for an omitted variable to affect the coefficient on the included regressor are that it must be correlated with the included regressor and it must have a non-zero coefficient in the equation of interest. The first condition, that the five-year job training treatment indicators are correlated with the included NIT treatment, is evident in Table 1 where the probability of receiving the job training treatment is correlated with NIT treatment status. In a simple random assignment, where each of these treatments is independently assigned, these two treatments would not be correlated. However, the Conlisk-Watts assignment model used by the SIME/DIME can result, and indeed does in this instance, in the treatment assignments being correlated. The second

22 The estimated job training effects found in the Final Report are shown in Appendix Table 1 for men in dual-headed households (Table 4.5, p. 224, United States Department of Health and Human Services 1983) and Appendix Table 2 for women in dual-headed households (Table 4.6, p. 225, United States Department of Health and Human Services 1983). The results from the re-analysis are presented in the main text since the Final Report does not present standard errors for the differential impact of job training across the three-year and five-year programs. The specifications used in the Final Report differ somewhat between the section that reports the NIT effects and the section that reports the job training effects. For consistency throughout the present study, the job training effects reported in Tables 2 and 3 are from the specifications that are used in Panel A of Table 5 and Panel A of Table 8, respectively.

23 According to the original program assignment, no five-year duration households were to be assigned to the counseling plus $100 \%$ tuition subsidy. As Table 1 shows, the data indicate that roughly $1 \%$ of households in the five-year program were enrolled in this program. The reason for this discrepancy is unclear. 
condition, that the coefficient on the five-year job training programs be different than the coefficient on the three-year job training programs, is evident in Tables 2 and 3. The impact of the job training treatment is larger in the five-year program relative to the three-year program for the second job training and statistically different in the second job training treatment one year for men and two years for women. As such, the omitted five-year job training treatment variables may bias the coefficient on the included five-year NIT treatment variable.

As is well-known, the textbook omitted variables bias scenario does not readily extend to more general cases. Even coefficients on variables that are uncorrelated with the omitted variable may in fact yield biased parameter estimates unless these additional variables are also uncorrelated with the included regressors. Notice that the regressors are mutually exclusive across program durations in the SIME/DIME. For example, households enrolled in a three-year NIT treatment cannot also be receiving treatment in a five-year job training program. This condition results in a negative correlation between these two regressors. Therefore, not only can excluding the five-year job training treatment indicators bias the coefficient on the five-year NIT treatment variable, it can also bias the coefficient on the three-year NIT treatment indicator.

A generalization of (1) that relaxes the first two assumptions is

$$
\begin{aligned}
H_{i t}-H_{i p} & =\alpha+\beta A_{i}+\gamma X_{i}+\phi_{5 Y R} I_{5 Y R, i} \\
& +\delta_{N I T, 3 Y R} T_{N I T, 3 Y R, i}+\delta_{N I T, 5 Y R} T_{N I T, 5 Y R, i} \\
& +\sum_{j=1}^{3} \psi_{J T, 3 Y R, j} T_{J T, 3 Y R, j, i}+\sum_{k=1}^{3} \psi_{J T, 5 Y R, k} T_{J T, 5 Y R, k, i}+\epsilon_{i t}
\end{aligned}
$$

where the model now includes separate regressors for the three-year job training program $\left(T_{J T, 3 Y R, j, i}, j=1,2,3\right)$ and the five-year job training program $\left(T_{J T, 5 Y R, k, i}, k=1,2,3\right)$. In addition, this model can be estimated with or without an indicator for being involved in the five-year program, $I_{5 Y R, i}$, which allows for differential effects for control households in the three- and five-year programs. Since the Final Report specification is nested within equation (2), estimating the general specification should yield the same results as the Final Report if omitted variables bias does not affect estimation of (1). 
The third assumption, which is the other focus of the re-analysis, is that there are no interaction effects across treatments. In other words, the impact of each job training treatment on work effort is independent of the household's NIT treatment assignment. Recall as mentioned earlier that the assignment model determined a joint probability of assignment for each NIT-job training treatment combination. In theory, one could estimate a treatment effect for each of these NIT-job training combinations. In practice, however, the SIME/DIME did not field a large enough sample to separately estimate each of these effects. In fact, page 26 of the Final Report notes that "the SIME/DIME sample of approximately 5,000 families would have had to be increased to 30,000 to find significant results" using a fully interacted model even without considering differences by program duration.

While the full set of NIT-job training combinations cannot be precisely estimated, a partial set of interactions between the two treatment assignments can be analyzed. A further generalization of (1) that relaxes the second and third assumptions is

$$
\begin{aligned}
H_{i t}-H_{i p} & =\alpha+\beta A_{i}+\gamma X_{i} \\
& +\delta_{\text {NITOnly }, 3 Y R} T_{\text {NITOnly }, 3 Y R, i}+\delta_{\text {NITOnly }, 5 Y R} T_{\text {NITOnly }, 5 Y R, i} \\
& +\delta_{J T O n l y, 3 Y R} T_{J T O n l y, 3 Y R, i}+\delta_{J T O n l y, 5 Y R} T_{J T O n l y, 5 Y R, i} \\
& +\delta_{N I T+J T, 3 Y R} T_{N I T+J T, 3 Y R, i}+\delta_{N I T+J T, 5 Y R} T_{N I T+J T, 5 Y R, i} \\
& +\sum_{j=2}^{3} \psi_{J T, 3 Y R, j} T_{J T, 3 Y R, j, i}+\sum_{k=2}^{3} \psi_{J T, 5 Y R, k} T_{J T, 5 Y R, k, i}+\epsilon_{i t}
\end{aligned}
$$

where the specification now includes, for each program duration, a mutually exclusive set of indicators for participation in the NIT experiment only $\left(T_{N I T O n l y, 3 Y R, i}, T_{N I T O n l y, 5 Y R, i}\right)$, participation in any job training experiment only $\left(T_{J T O n l y, 3 Y R, i}, T_{J T O n l y, 5 Y R, i}\right)$, and participation in both the NIT and job training experiments $\left(T_{N I T+J T, 3 Y R, i}, T_{N I T+J T, 5 Y R, i}\right)$. The above model still allows for a differential impact for each of the three job training treatments by program duration as can be seen by the terms that include the summation signs. However, the relative impact of, say, the 50 percent tuition subsidy on labor supply is restricted to be the same by program duration for households in the job training only treatment as it is for households enrolled in both experiments. Thus, estimation of equation (3) allows for both the second and third assumptions of the Final Report specification 
to be relaxed while still maintaining some restrictions in order to address the concerns about precision in the estimated parameters.

\section{Results for Men in Dual-Headed Households}

Figure 1b presents the results of using the data from the Work Impact files to estimate the Final Report specification shown in equation (1). The results from the re-analysis in Figure 1b are very similar to those found in the Final Report which are shown in Figure 1a. Hours of work fully adjust to their experimental level by the second year of the experiment and essentially remain constant until the end of the experiment. The reduction in work hours is greater for households in the five-year experiment than those in the three-year experiment. Finally, for each treatment duration group, there are no differences in work hours between the treatment and control households once the experiment ends.

The results found in Figure $1 \mathrm{~b}$ are also shown in Panel B of Table 4. For comparison, the analogous results from the Final Report are shown in Panel A of Table 4. As illustrated in the Figures, the point estimates from the Final Report and those from the re-analysis using the Work Impact files are very similar. If anything, the estimated impact of the experiment is slightly larger in the re-analysis but the results are well within the confidence intervals of the Final Report estimates. In addition, the first column of Panel B shows that in the re-analysis there are no pre-experimental differences in hours worked between the controls and either treatment duration group. ${ }^{24}$

The estimated differences in hours worked by treatment duration found in the Final Report are nearly identical to those estimated in the re-analysis. For example, the bottom of Panel A of Table 4 indicates that the difference in the first year of the experiment is -78.2 annual hours with a t-statistic of 2.14. The analogous result in the re-analysis (Panel B) is -75.8 with a t-statistic of 2.07. The findings for the remaining experimental years are also very similar. Thus, the re-analysis using the same sample specification yields results that are essentially the same as those found in the Final Report.

24 Estimates of the pre-experimental labor supply differences use the same specification as shown in (1) except that the dependent variable is $H_{i p}$ rather than $H_{i t}-H_{i p}$ and $H_{i p}$ is not included as a regressor. 
As discussed above, nearly all analyses of the SIME/DIME do not control for whether the household was enrolled in the three-year or five-year job training experiment. Panel A of Table 5 and Figure 2a present the results of estimating (2) which allows for the impact of the job training experiment to vary across the three- and five-year treatments. ${ }^{25}$ The findings still indicate that there is a significant reduction in hours worked relative to the control households for both the three- and five-year NIT treatment groups. However, the difference in the impact by treatment duration is no longer statistically significant. While the t-statistic for the difference is close to being marginally significant (1.54) in the first year of the experiment, the t-statistic is below 1 in the second and third year of the experiment. The differences between the three- and five-year program durations remain significant during years four and five when the experimental period has ended for the three-year treatment but continues for the five-year experiment. However, the magnitude of the difference during this period is also somewhat smaller than the findings from the Final Report.

To see more clearly the impact that allowing the effect of the job training experiment to differ by program duration has on the estimated NIT treatment duration differences, Figures $3 \mathrm{a}$ and $3 \mathrm{~b}$ plot these differences using the Final Report specification (Panel B of Table 4) and the specification that controls for the job training treatment duration (Panel A of Table 5), respectively. The solid line in these Figures is the point estimate for the program duration differences while the dashed lines are the bounds of the 95 percent confidence intervals. The addition of the job training duration controls has little effect on the magnitude of the NIT duration differences in the first year of the experiment although the difference becomes insignificant. The estimated differences fall by 50 percent, however, in the second and third experimental year and are now statistically insignificant. Thus, correcting the specification only for the job training program duration leads to an insignificant finding for the NIT treatment duration differences.

Another characteristic of the experiment that was not accounted for in the Final Report specification is the assignment of the control households to either the three- or five-year

25 However, the regressor for being in the five-year program, $I_{5 Y R, i}$, is still excluded from the model at this point. 
program duration. As mentioned above in the description of the experiment, assignment to the three- or five-year program is random conditional upon race, family type, normal income group, and site. Therefore, including an indicator for program duration assignment of a household - whether involved in the NIT experiment, the job training experiment, or a control - should not impact the findings. However, given that the treatment response to both the NIT experiment as well as to the job training experiment is allowed to vary by program duration, allowing for a differential effect for the control group by program duration provides a more flexible specification.

Panel B of Table 5 presents the estimates of equation (2) which not only allows for the impact of the job training experiment to vary across the three- and five-year treatment but also includes an indicator for being involved in the five-year experiment, $I_{5 Y R, i}$. The indicator for being enrolled in the five-year experiment is negative and insignificant in the first four experimental years and becomes marginally significant in the fifth experimental year. These findings are somewhat surprising since random assignment to the three- or fiveyear program should have led these estimated coefficients to equal zero. The insignificant coefficients on this indicator can still be viewed, however, as evidence that assignment to program duration was indeed random.

Figure $2 \mathrm{~b}$ plots the impact of the NIT treatment by program duration for the specification that also includes a program duration indicator while the duration differences are shown in Figure 3c. The estimated differences shrink even further relative to those that only adjust for the job training duration differences. The t-statistics for the estimated differences (Panel B of Table 5) are below 0.6 for the three years during which both program duration groups are exposed to the treatment.

Overall, as can be seen clearly in Figures 3a-3c, adjusting the basic specification used in the Final Report to account for the job training experimental duration decreases the NIT treatment duration differences in magnitude by at least 50 percent and the estimated differences become statistically insignificant. The additional adjustment for the program duration assignment of the control households further confirms the lack of a significant differential impact of the NIT by program duration. These findings are in stark contrast to the estimates found when using the Final Report specification. 
In addition to an omitted variables bias, the other potential source of specification error in the model used in the Final Report is the assumption of an additive treatment response by households enrolled in both programs to each individual experiment. Table 6 shows the results of estimating (3) which allows for mutually exclusive treatment effects for households enrolled in one of the two experiments as well as for households assigned to both experiments. The set of results presented in the first three rows of the Table shows the differential effects for households enrolled only in the job training experiment. Consistent with the findings in Table 2, households in the five-year job training treatment show a larger labor supply response than those in the three-year program although the estimates are not statistically different. The middle set of results shown in Table 6 present a surprising set of labor supply responses for men enrolled only in the NIT experiment. The treatment response by men in the five-year NIT experiment is significantly larger than by men in the three-year NIT experiment during the first two years of the experiment. These results are especially surprising given the findings in Table 5 where the NIT labor supply response between men in the three- and five-year programs is not statistically different.

What can explain the differences between the NIT experiment only findings in Table 6 and the results presented in Table 5? The results in the final three rows of Table 6 can reconcile these two sets of seemingly disparate empirical findings. For households enrolled in both the NIT and the job training experiments, the differences in the labor supply responses are not statistically different across the three- and five-year treatments during the first three experimental years. Moreover, the point estimates of the differences during the first two experimental years are almost zero. These results indicate there are no treatment duration differences among households enrolled in both experiments but that those households enrolled in the NIT only experiment do experience treatment duration differences.

While this last set of results explains the differences in findings for the NIT experiment when estimating equations (2) and (3), these results are hard to reconcile with a simple model of the treatment response to the income and substitution effects of the NIT and job training programs. The sum of the differences between the three- and five-year treatments for the job training only households and the NIT only households is far greater than the 
estimated differences for households that are simultaneously enrolled in both experiments. In addition, the additivity assumption for the individual program effects is rejected for the first two experimental years for five-year program households. ${ }^{26}$ More puzzling, however, is that among five-year program households the labor supply response for the NIT only experiment is larger than for households enrolled in both experiments although these differences are insignificant. It is unclear what theoretical model would explain these differences between households only enrolled in the NIT and those enrolled in both experiments.

\section{Results for Women in Dual-Headed Households}

Table 7 presents findings from the Final Report for women in dual-headed households along with the re-analysis of the SIME/DIME data. According to the Final Report (Panel A of Table 7), significantly larger effects are found for the five-year treatment group in the first two experimental years. ${ }^{27}$ The estimated impact is also larger in the third experimental year although the difference is not statistically significant.

As shown in Figure 4b and Panel B of Table 7, nearly identical results are found in the re-analysis of the data using the Final Report specification. As with the men, the NIT treatment duration differences are nearly identical in the Final Report and in the reanalysis. For example, the difference in hours worked between treatment duration groups in the second year of the experiment is -79.9 in the Final Report and -75.2 in the reanalysis. One slight difference to note is the significance level for these differences. While the duration differences are significant in the Final Report for the first two years of the experiment, these differences are only marginally significant in the re-analysis.

The results when including separate job training treatment indicators by program duration are presented in Panel A of Table 8 along with Figure 5a. During the first three experimental years, the treatment duration differences upon implementing this adjustment are roughly two-thirds smaller in magnitude. None of these estimates are statistically significant while the largest t-statistic is only 0.61. As shown both in Panel B of Table 8 and

\footnotetext{
26 In results not shown here, the null hypothesis that the sum of the two individual five-year treatment effects equals the treatment effect for households enrolled in both five-year experiments is rejected at the 0.05 level in the first experimental year and at the 0.10 level in the second experimental year.

27 These results are found in Table 3.5 on p.121 of the Final Report.
} 
in Figure 5b, further adjusting the specification for enrollment in the five-year program, regardless of treatment status, also leads to insignificant NIT treatment duration differences for women in dual-head households. The impact on the treatment duration differences of changing the specification is plotted in Figures 6a, 6b, and 6c. As with the men, women in dual-headed households exhibit a small and insignificant difference in work effort across the three- and five-year treatment durations.

Table 9 presents the results of estimating (3) for women in dual-headed households. Unlike the results for men, there are no treatment duration differences when the additivity assumption is relaxed. Also, in results not shown here, the findings for women in Table 9 cannot reject that the sum of the labor supply impact of the two individual experiments equals the treatment effect for households enrolled in both experiments. The additivity assumption appears to be especially true in years two and three of the experiment where the differences between the sum of the NIT only and job training only effects and the effect of being enrolled in both experiments is less than two hours in two cases and less than 13 hours in another instance. Thus, this alternative specification further suggests that specification bias is responsible for the Final Report finding that there are differences in the labor supply response between the three- and five-year NIT treatments.

Finally, Table 10 presents both the results from the Final Report as well as a re-analysis of the SIME/DIME for women in single-headed households. The Final Report estimates (Panel A) indicate that the treatment duration differences are small and statistically insignificant. The replication of the original findings (Panel B) shows essentially non-existent differences between the different NIT treatment duration groups. In results not shown here, applying the same specification adjustments to this set of respondents as are applied above continues to yield small and insignificant differences across the two groups.

\section{Discussion of Implications for Life-Cycle Labor Supply Models}

As mentioned in the introduction, the results from the Final Report presented in Figure 1a have been interpreted as evidence against the standard life-cycle labor supply model. According to Ashenfelter (1984, p.19), these results "are not easily explained by the lifecycle model..." Browning, Deaton, and Irish (1985, p.538) state that the "perhaps most 
convincing" evidence against the life-cycle model is the SIME/DIME duration results. What prediction of the life-cycle model is contradicted by the SIME/DIME results?

Browning, Deaton, and Irish further elaborate on the difference between the predictions of the life-cycle model and the findings reported in the Final Report. As shown in Figure 1a,

"those enrolled in the five-year [treatment] program [reduced their hours relative to the controls] by more than those enrolled in the three-year [treatment] program. This is consistent with the existence of life-cycle income effects as predicted by the theory. However, in both the three and five year [treatment] programs, there is no continuing evidence of hours reduction beyond the end of the experiment, contradicting the income effects explanation. It is far from clear what theory would explain this evidence, but it is certainly not the standard life-cycle one" (Browning, Deaton, and Irish 1985, p.538).

Notice, however, that the results from the re-analysis shown in Figures 2a and 5a that control for the job training program duration are consistent with the life-cycle model. Not only does the re-analysis find no difference in work effort during the experimental period due to program duration, but there also is no treatment duration difference in the postexperimental period. The change in labor supply at the end of the experiment is the same across NIT treatment households in both program durations. When the assumption that NIT and job training treatment effects are additive is relaxed, the findings still suggest no program duration differences for women. For men, the story is somewhat more complicated. Among men enrolled in both experiments, there remain no treatment duration differences. However, the re-analysis results are similar to those found in the Final Report for men enrolled in the NIT treatment only. It is puzzling, though, to find that the labor supply responses for men enrolled only in the NIT are larger than for men who participate in both treatments. While the standard life-cycle model cannot explain these findings, it is unclear what model can explain these results. Overall, the findings in the re-analysis suggest the previous concerns about the consistency of the SIME/DIME findings with the predictions from the life-cycle labor supply model should be alleviated. 
Can the insignificant treatment duration differences be reconciled with the life-cycle labor supply model? The point estimates of the treatment duration differences, while small and insignificant, tend to be negative in sign. One interpretation is that the wealth effect of the five-year treatment duration is indeed larger than that of the three-year treatment but this difference cannot be discerned in the SIME/DIME due to sampling variability. In addition, the results of the re-analysis (as well as in the Final Report) indicate that in the post-experimental period, the work effort of treated households is similar to that of the control households. Combining these findings suggests that most of the SIME/DIME labor supply response is driven by intertemporal substitution. 


\section{Bibliography}

Abowd, John M. and David Card (1989) "On the Covariance Structure of Earnings and Hours Changes," Econometrica, 57, 2, 411-45.

Ashenfelter, Orley (1984) "Macroeconomic Analyses and Microeconomic Analyses of Labor Supply," Carnegie-Rochester Conference Series on Public Policy, 21, 117-55.

Browning, Martin, Angus Deaton, and Margaret Irish (1985) "A Profitable Approach to Labor Supply and Commodity Demands over the Life-Cycle," Econometrica, 53, 3, $503-43$.

Burtless, Gary and David Greenberg (1982) "Inferences Concerning Labor Supply Behavior Based on Limited-Duration Experiments," American Economic Review, 72, 3, 488-97.

Burtless, Gary and Jerry A. Hausman (1978) "The Effect of Taxation on Labor Supply: Evaluating the Gary Negative Income Tax Experiment," The Journal of Political Economy, 86, 6, 1103-30.

Cain, Glen G. and Douglas A. Wissoker (1990a) "A Reanalysis of Marital Stability in the Seattle-Denver Income-Maintenance Experiment," American Journal of Sociology, 95, $5,1235-69$.

Cain, Glen G. and Douglas A. Wissoker (1990b) "Response to Hannan and Tuma," American Journal of Sociology, 95, 5, 1299-1314.

Conlisk, John and Mordecai Kurz (1972) "The Assignment Model of the Seattle and Denver Income Maintenance Experiments," Stanford Research Institute Research Memorandum 15.

Hannan, Michael T. and Nancy Brandon Tuma (1990) "A Reassessment of the Effect of Income Maintenance on Marital Dissolution in the Seattle-Denver Experiment," American Journal of Sociology, 95, 5, 1270-98.

Hausman, Jerry A. and David A. Wise (1979) "Attrition Bias in Experimental and Panel Data: The Gary Income Maintenance Experiment," Econometrica, 47, 2, 455-74. 
Heckman, James, Neil Hohmann, and Jeffrey Smith with the assistance of Michael Khoo (2000) "Substitution and Dropout Bias in Social Experiments: A Study of an Influential Social Experiment," Quarterly Journal of Economics, 115, 2, 651-94.

Heckman, James J., Robert J. LaLonde, and Jeffrey A. Smith (1999) "The Economics and Econometrics of Active Labor Market Programs," in Handbook of Labor Economics, Volume 3, eds. Orley Ashenfelter and David Card. Amsterdam: Elsevier Science Publishers BV.

Keeley, Michael C. and Philip K. Robins (1980) "The Design of Social Experiments: A Critique of the Conlisk-Watts Assignment Model and Its Application to the Seattle and Denver Income Maintenance Experiments," Research in Labor Economics, 3, 293-333.

Keeley, Michael C., Philip K. Robins, Robert G. Spiegelman, and Richard W. West (1978) "The Estimation of Labor Supply Models Using Experimental Data," American Economic Review, 68, 5, 873-87.

MaCurdy, Thomas (1981) "An Empirical Model of Labor Supply in a Life-Cycle Setting," Journal of Political Economy, 89, 6, 1059-85.

Robins, Philip K. (1984) "The Labor Supply Response of Twenty-Year Families in the Denver Income Maintenance Experiment," Review of Economics and Statistics, 66, 3, 491-95.

Robins, Philip K. and Richard W. West (1980) "Labor Supply Response over Time," Journal of Human Resources, 15, 4, 524-44.

Robins, Philip K. and Richard W. West (1986) "Sample Attrition and Labor Supply Response in Experimental Panel Data," Journal of Business and Economic Statistics, 4, $3,329-38$.

Spiegelman, Robert G. and K. E. Yaeger (1980) "The Seattle and Denver Income Maintenance Experiments: Overview," Journal of Human Resources, 15, 4, 463-79.

United States Department of Health and Human Services (1983) Final Report of the Seattle-Denver Income Maintenance Experiment. Washington: United States Depart- 
ment of Health and Human Services.

United States Department of Health and Human Services (1985) Seattle/Denver Income Maintenance Experiment Documentation. Washington: National Archives and Records Administration.

Wooldridge, Jeffrey M. (2002) Econometric Analysis of Cross Section and Panel Data. Cambridge, MA: The MIT Press. 


\begin{tabular}{|c|c|c|c|c|c|c|}
\hline \multicolumn{7}{|c|}{$\begin{array}{c}\text { TABLE } 1 \text { - DISTRIBUTION OF TREATMENT STATUS BY PROGRAM DURATION } \\
\text { SINGLE-HEADED AND DUAL-HEADED HOUSEHOLDS } \\
\text { AUTHOR'S CALCULATIONS }\end{array}$} \\
\hline & \multicolumn{3}{|c|}{ Three-Year Program Households } & \multicolumn{3}{|c|}{ Five-Year Program Households } \\
\hline & $\begin{array}{c}\text { NIT } \\
\text { Control }\end{array}$ & $\begin{array}{c}\text { NIT } \\
\text { Treatment }\end{array}$ & Total & $\begin{array}{c}\text { NIT } \\
\text { Control }\end{array}$ & $\begin{array}{c}\text { NIT } \\
\text { Treatment }\end{array}$ & Total \\
\hline Job Training Control & $\begin{array}{c}582 \\
(18 \%)\end{array}$ & $\begin{array}{c}610 \\
(19 \%)\end{array}$ & $\begin{array}{c}1192 \\
(37 \%)\end{array}$ & $\begin{array}{c}453 \\
(29 \%)\end{array}$ & $\begin{array}{c}334 \\
(22 \%)\end{array}$ & $\begin{array}{c}787 \\
(51 \%)\end{array}$ \\
\hline Job Training Treatment & $\begin{array}{c}725 \\
(22 \%)\end{array}$ & $\begin{array}{c}1322 \\
(41 \%)\end{array}$ & $\begin{array}{c}2047 \\
(63 \%)\end{array}$ & $\begin{array}{c}286 \\
(18 \%)\end{array}$ & $\begin{array}{c}481 \\
(31 \%)\end{array}$ & $\begin{array}{c}767 \\
(49 \%)\end{array}$ \\
\hline Counseling Only & $\begin{array}{c}219 \\
(7 \%)\end{array}$ & $\begin{array}{c}370 \\
(11 \%)\end{array}$ & $\begin{array}{c}589 \\
(18 \%)\end{array}$ & $\begin{array}{l}119 \\
(8 \%)\end{array}$ & $\begin{array}{c}210 \\
(13 \%)\end{array}$ & $\begin{array}{c}339 \\
(21 \%)\end{array}$ \\
\hline $\begin{array}{c}\text { Counseling Plus } \\
\text { 50\% Subsidy }\end{array}$ & $\begin{array}{c}248 \\
(8 \%)\end{array}$ & $\begin{array}{c}497 \\
(15 \%)\end{array}$ & $\begin{array}{c}745 \\
(23 \%)\end{array}$ & $\begin{array}{c}166 \\
(11 \%)\end{array}$ & $\begin{array}{c}260 \\
(17 \%)\end{array}$ & $\begin{array}{c}426 \\
(27 \%)\end{array}$ \\
\hline $\begin{array}{l}\text { Counseling Plus } \\
100 \% \text { Subsidy }\end{array}$ & $\begin{array}{l}258 \\
(8 \%)\end{array}$ & $\begin{array}{c}455 \\
(14 \%)\end{array}$ & $\begin{array}{c}713 \\
(22 \%)\end{array}$ & $\begin{array}{c}1 \\
(0 \%)\end{array}$ & $\begin{array}{c}11 \\
(1 \%)\end{array}$ & $\begin{array}{c}12 \\
(1 \%)\end{array}$ \\
\hline Total & $\begin{array}{l}1307 \\
(40 \%)\end{array}$ & $\begin{array}{c}1932 \\
(60 \%)\end{array}$ & & $\begin{array}{c}739 \\
(48 \%)\end{array}$ & $\begin{array}{c}815 \\
(52 \%)\end{array}$ & \\
\hline
\end{tabular}

Note: Percentages in parentheses are the share of households in the given program duration that fall within the cell. 


\begin{tabular}{|c|c|c|c|c|c|c|}
\hline \multicolumn{7}{|c|}{$\begin{array}{c}\text { TABLE } 2 \text { - IMPACT OF THE SIME/DIME JOB TRAINING EXPERIMENT ON HOURS WORKED } \\
\text { RE-ANALYSIS USING FINAL REPORT SPECIFICATION } \\
\text { MEN IN DUAL-HEADED HOUSEHOLDS }\end{array}$} \\
\hline & Year 1 & Year 2 & Year 3 & Year 4 & Year 5 & Year 6 \\
\hline \multicolumn{7}{|l|}{ Counseling Only: } \\
\hline Three-Year Treatment & $\begin{array}{c}-6.9 \\
(44.2)\end{array}$ & $\begin{array}{c}18.9 \\
(52.5)\end{array}$ & $\begin{array}{c}52.6 \\
(59.2)\end{array}$ & $\begin{array}{c}44.8 \\
(60.1)\end{array}$ & $\begin{array}{c}-1.4 \\
(94.1)\end{array}$ & \\
\hline Five-Year Treatment & $\begin{array}{c}7.2 \\
(57.5)\end{array}$ & $\begin{array}{c}23.2 \\
(68.3)\end{array}$ & $\begin{array}{c}-41.6 \\
(77.0)\end{array}$ & $\begin{array}{l}-61.6 \\
(78.2)\end{array}$ & $\begin{array}{c}1.1 \\
(85.7)\end{array}$ & $\begin{array}{c}-89.0 \\
(87.9)\end{array}$ \\
\hline Five-Year - Three-Year Impact & $\begin{array}{c}14.1 \\
(69.9)\end{array}$ & $\begin{array}{c}4.3 \\
(82.9)\end{array}$ & $\begin{array}{l}-94.2 \\
(93.6)\end{array}$ & $\begin{array}{c}-106.3 \\
(95.0)\end{array}$ & $\begin{array}{c}2.5 \\
(121.8)\end{array}$ & \\
\hline \multicolumn{7}{|l|}{ Counseling Plus 50 Percent Subsidy: } \\
\hline Three-Year Treatment & $\begin{array}{l}-33.5 \\
(39.7)\end{array}$ & $\begin{array}{c}75.4 \\
(47.1)\end{array}$ & $\begin{array}{c}91.1 \\
(53.2)\end{array}$ & $\begin{array}{c}30.5 \\
(54.0)\end{array}$ & $\begin{array}{l}-23.2 \\
(75.8)\end{array}$ & \\
\hline Five-Year Treatment & $\begin{array}{l}-70.9 \\
(47.5)\end{array}$ & $\begin{array}{l}-81.9 \\
(56.3)\end{array}$ & $\begin{array}{c}-23.2 \\
(63.6)\end{array}$ & $\begin{array}{c}-71.2 \\
(64.5)\end{array}$ & $\begin{array}{l}-83.7 \\
(70.3)\end{array}$ & $\begin{array}{c}-60.8 \\
(72.4)\end{array}$ \\
\hline Five-Year - Three-Year Impact & $\begin{array}{l}-37.4 \\
(58.2)\end{array}$ & $\begin{array}{c}-157.3 \\
(69.0)\end{array}$ & $\begin{array}{l}-114.3 \\
(77.9)\end{array}$ & $\begin{array}{l}-101.7 \\
(79.1)\end{array}$ & $\begin{array}{l}-60.5 \\
(95.6)\end{array}$ & \\
\hline \multicolumn{7}{|c|}{ Counseling Plus 100 Percent Subsidy: } \\
\hline Three-Year Treatment Only & $\begin{array}{l}-52.4 \\
(39.8)\end{array}$ & $\begin{array}{l}-28.0 \\
(47.2)\end{array}$ & $\begin{array}{l}-34.9 \\
(53.3)\end{array}$ & $\begin{array}{l}-18.8 \\
(54.1)\end{array}$ & $\begin{array}{l}-36.5 \\
(75.7)\end{array}$ & \\
\hline
\end{tabular}




\begin{tabular}{lcccc}
\hline \multicolumn{5}{c}{ TABLE 3 - IMPACT OF THE SIME/DIME JOB TRAINING EXPERIMENT ON HOURS WORKED } \\
RE-ANALYSIS USING FINAL REPORT SPECIFICATION \\
\\
WOMEN IN DUAL-HEADED HOUSEHOLDS
\end{tabular}




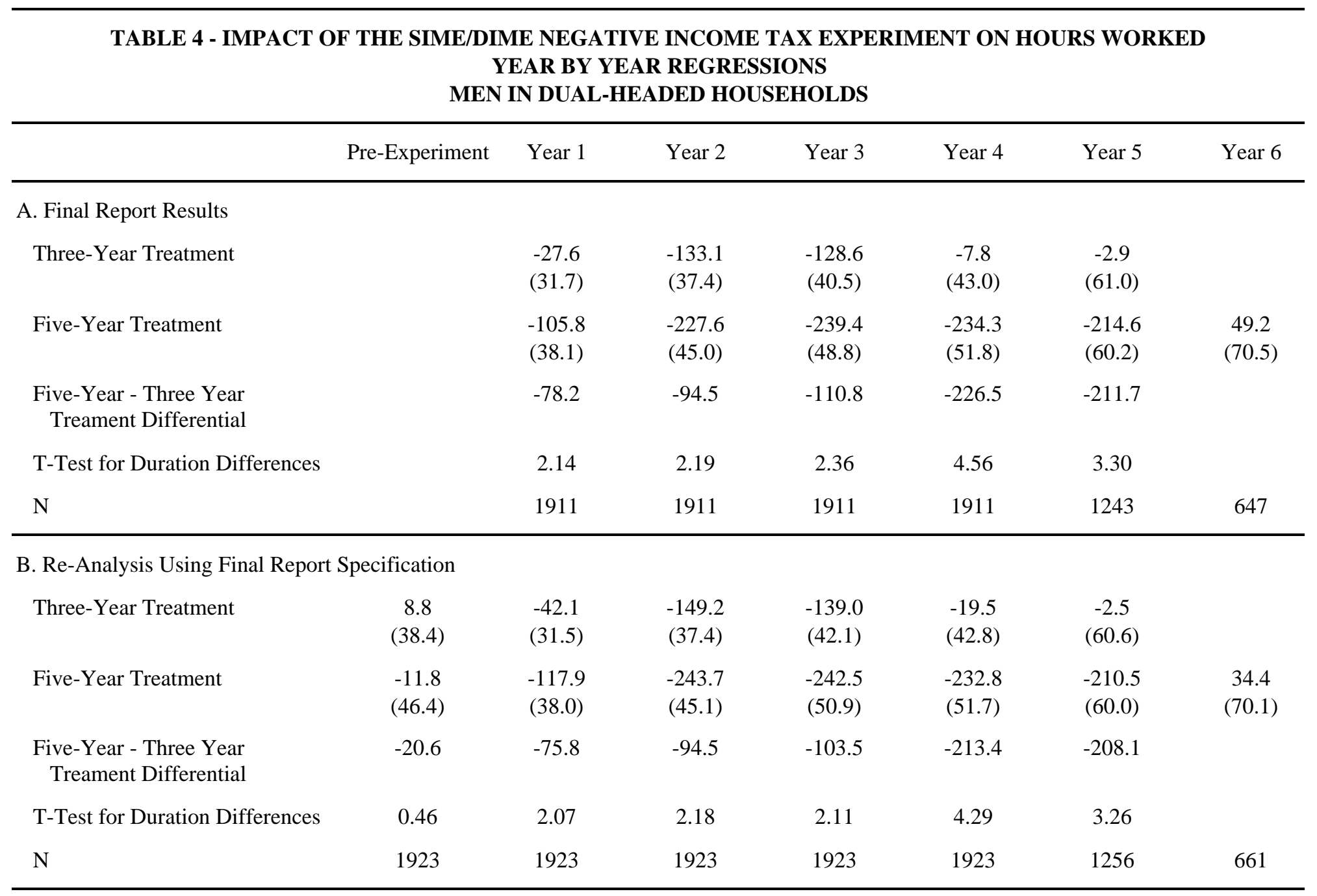




\begin{tabular}{|c|c|c|c|c|c|c|c|}
\hline \multicolumn{8}{|c|}{$\begin{array}{c}\text { TABLE } 5 \text { - IMPACT OF THE SIME/DIME NEGATIVE INCOME TAX EXPE } \\
\text { YEAR BY YEAR REGRESSIONS } \\
\text { MEN IN DUAL-HEADED HOUSEHOLDS }\end{array}$} \\
\hline & Pre-Experiment & Year 1 & Year 2 & Year 3 & Year 4 & Year 5 & Year 6 \\
\hline \multicolumn{8}{|c|}{ A. Re-Analysis Including Job Training Duration Indicators } \\
\hline Three-Year Treatment & $\begin{array}{l}-14.1 \\
(39.8)\end{array}$ & $\begin{array}{l}-44.6 \\
(32.6)\end{array}$ & $\begin{array}{l}-165.7 \\
(38.7)\end{array}$ & $\begin{array}{l}-156.8 \\
(43.7)\end{array}$ & $\begin{array}{l}-37.0 \\
(44.4)\end{array}$ & $\begin{array}{l}-14.9 \\
(65.8)\end{array}$ & \\
\hline Five-Year Treatment & $\begin{array}{c}45.4 \\
(52.5)\end{array}$ & $\begin{array}{l}-116.3 \\
(43.1)\end{array}$ & $\begin{array}{l}-213.7 \\
(51.1)\end{array}$ & $\begin{array}{l}-205.0 \\
(57.6)\end{array}$ & $\begin{array}{l}-193.9 \\
(58.5)\end{array}$ & $\begin{array}{l}-196.5 \\
(65.7)\end{array}$ & $\begin{array}{l}16.0 \\
(70.5)\end{array}$ \\
\hline $\begin{array}{l}\text { Five-Year - Three Year } \\
\text { Treament Differential }\end{array}$ & 59.5 & -71.7 & -48.0 & -48.2 & -156.9 & -181.5 & \\
\hline T-Test for Duration Differences & 1.05 & 1.54 & 0.87 & 0.77 & 2.48 & 2.20 & \\
\hline $\mathrm{N}$ & 1923 & 1923 & 1923 & 1923 & 1923 & 1256 & 661 \\
\hline \multicolumn{8}{|c|}{ B. Re-Analysis Including Job Training Duration Indicators and a Five-Year Program Indicator } \\
\hline Five-Year Program & $\begin{array}{c}44.6 \\
(58.3)\end{array}$ & $\begin{array}{l}-64.3 \\
(47.9)\end{array}$ & $\begin{array}{l}-82.7 \\
(56.8)\end{array}$ & $\begin{array}{l}-35.5 \\
(64.1)\end{array}$ & $\begin{array}{l}-93.6 \\
(65.0)\end{array}$ & $\begin{array}{l}-140.7 \\
(83.1)\end{array}$ & $\begin{array}{c}-96.6 \\
(114.9)\end{array}$ \\
\hline Three-Year Treatment & $\begin{array}{c}-2.7 \\
(42.5)\end{array}$ & $\begin{array}{l}-61.1 \\
(34.9)\end{array}$ & $\begin{array}{l}-186.9 \\
(41.4)\end{array}$ & $\begin{array}{l}-165.9 \\
(46.7)\end{array}$ & $\begin{array}{l}-61.1 \\
(47.4)\end{array}$ & $\begin{array}{l}-50.4 \\
(69.0)\end{array}$ & \\
\hline Five-Year Treatment & $\begin{array}{c}29.5 \\
(56.5)\end{array}$ & $\begin{array}{l}-93.3 \\
(46.3)\end{array}$ & $\begin{array}{l}-184.2 \\
(54.9)\end{array}$ & $\begin{array}{l}-192.3 \\
(62.0)\end{array}$ & $\begin{array}{l}-160.5 \\
(62.9)\end{array}$ & $\begin{array}{l}-162.9 \\
(68.6)\end{array}$ & $\begin{array}{c}28.2 \\
(72.0)\end{array}$ \\
\hline $\begin{array}{l}\text { Five-Year - Three Year } \\
\text { Treament Differential }\end{array}$ & 32.1 & -32.2 & 2.7 & -26.4 & -99.4 & -112.5 & \\
\hline T-Test for Duration Differences & 0.48 & 0.59 & 0.04 & 0.36 & 1.33 & 1.22 & \\
\hline $\mathrm{N}$ & 1923 & 1923 & 1923 & 1923 & 1923 & 1256 & 661 \\
\hline
\end{tabular}




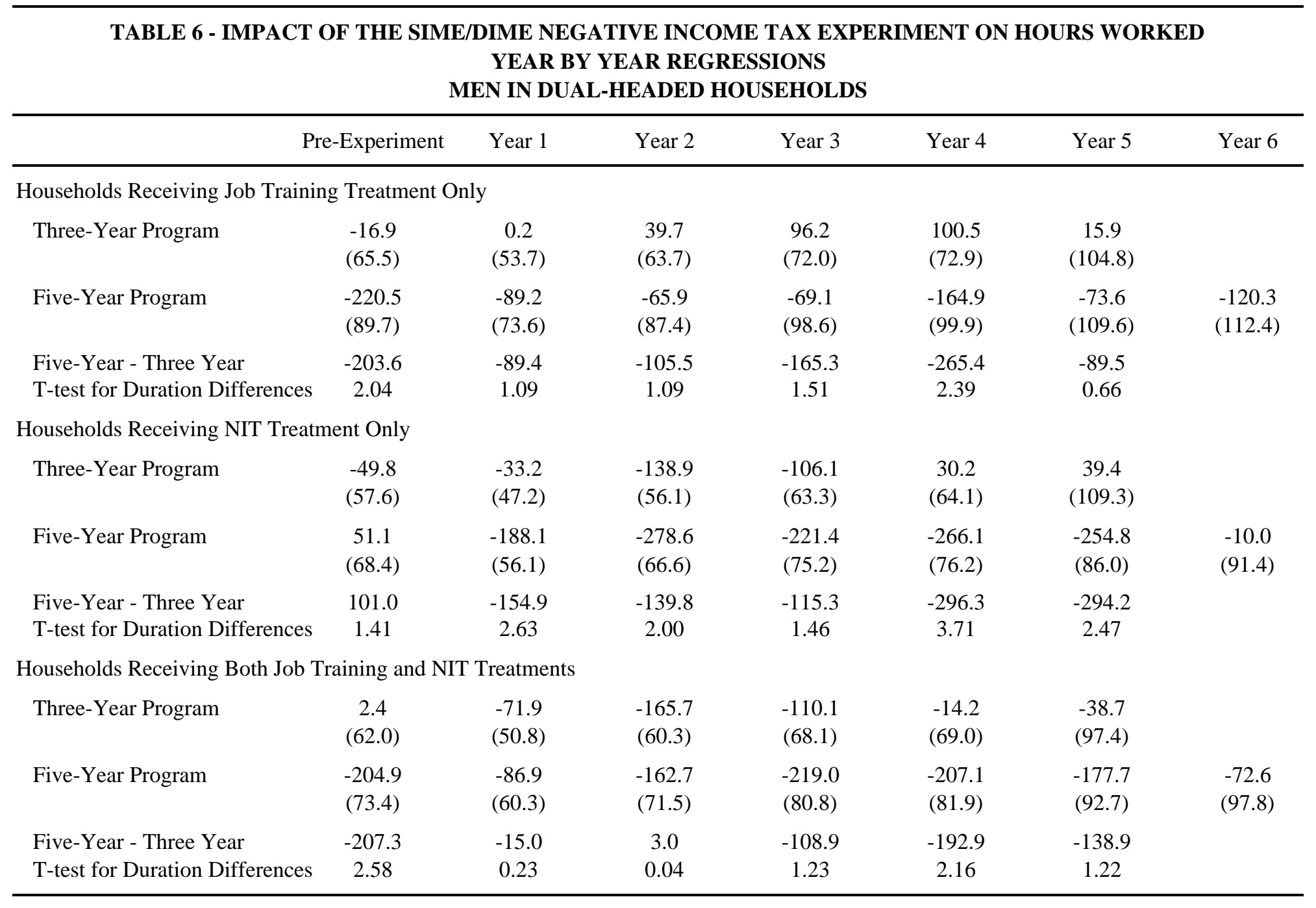









\begin{tabular}{|c|c|c|c|c|c|c|c|}
\hline \multicolumn{8}{|c|}{$\begin{array}{c}\text { TABLE } 8 \text { - IMPACT OF THE SIME/DIME NEGATIVE INCOME TAX EXPER } \\
\text { YEAR BY YEAR REGRESSIONS } \\
\text { WOMEN IN DUAL-HEADED HOUSEHOLDS }\end{array}$} \\
\hline & Pre-Experiment & Year 1 & Year 2 & Year 3 & Year 4 & Year 5 & Year 6 \\
\hline \multicolumn{8}{|c|}{ A. Re-Analysis Including Job Training Duration Indicators } \\
\hline Three-Year Treatment & $\begin{array}{l}-75.6 \\
(39.8)\end{array}$ & $\begin{array}{l}-38.0 \\
(30.4)\end{array}$ & $\begin{array}{l}-112.3 \\
(36.8)\end{array}$ & $\begin{array}{l}-114.8 \\
(40.0)\end{array}$ & $\begin{array}{l}-15.3 \\
(42.1)\end{array}$ & $\begin{array}{c}96.2 \\
(65.7)\end{array}$ & \\
\hline Five-Year Treatment & $\begin{array}{l}-11.6 \\
(52.2)\end{array}$ & $\begin{array}{l}-64.3 \\
(39.8)\end{array}$ & $\begin{array}{l}-136.0 \\
(48.2)\end{array}$ & $\begin{array}{l}-120.6 \\
(52.4)\end{array}$ & $\begin{array}{l}-174.4 \\
(55.2)\end{array}$ & $\begin{array}{l}-190.5 \\
(64.9)\end{array}$ & $\begin{array}{l}-36.6 \\
(72.0)\end{array}$ \\
\hline $\begin{array}{l}\text { Five-Year - Three Year } \\
\text { Treament Differential }\end{array}$ & 64.0 & -26.2 & -23.6 & -5.7 & -159.0 & -286.7 & \\
\hline T-Test for Duration Differences & 1.14 & 0.61 & 0.46 & 0.10 & 2.67 & 3.52 & \\
\hline $\mathrm{N}$ & 2074 & 2074 & 2074 & 2074 & 2074 & 1373 & 726 \\
\hline \multicolumn{8}{|c|}{ B. Re-Analysis Including Job Training Duration Indicators and a Five-Year Program Indicator } \\
\hline Five-Year Program & $\begin{array}{l}109.6 \\
(58.5)\end{array}$ & $\begin{array}{c}65.9 \\
(44.6)\end{array}$ & $\begin{array}{l}-33.8 \\
(54.0)\end{array}$ & $\begin{array}{l}-118.1 \\
(58.7)\end{array}$ & $\begin{array}{l}-88.1 \\
(61.9)\end{array}$ & $\begin{array}{l}-15.4 \\
(83.2)\end{array}$ & $\begin{array}{c}60.7 \\
(119.0)\end{array}$ \\
\hline Three-Year Treatment & $\begin{array}{l}-46.9 \\
(42.7)\end{array}$ & $\begin{array}{l}-20.8 \\
(32.5)\end{array}$ & $\begin{array}{l}-121.1 \\
(39.4)\end{array}$ & $\begin{array}{l}-145.6 \\
(42.8)\end{array}$ & $\begin{array}{l}-38.3 \\
(45.1)\end{array}$ & $\begin{array}{c}92.1 \\
(69.3)\end{array}$ & \\
\hline Five-Year Treatment & $\begin{array}{l}-51.0 \\
(56.3)\end{array}$ & $\begin{array}{l}-88.0 \\
(42.9)\end{array}$ & $\begin{array}{l}-123.8 \\
(52.0)\end{array}$ & $\begin{array}{l}-78.0 \\
(56.4)\end{array}$ & $\begin{array}{c}-142.6 \\
(59.5)\end{array}$ & $\begin{array}{l}-186.8 \\
(67.9)\end{array}$ & $\begin{array}{l}-43.8 \\
(73.4)\end{array}$ \\
\hline $\begin{array}{l}\text { Five-Year - Three Year } \\
\text { Treament Differential }\end{array}$ & -4.2 & -67.2 & -2.6 & 67.6 & -104.3 & -278.9 & \\
\hline T-Test for Duration Differences & 0.06 & 1.32 & 0.04 & 1.01 & 1.47 & 3.05 & \\
\hline $\mathrm{N}$ & 2074 & 2074 & 2074 & 2074 & 2074 & 1373 & 726 \\
\hline
\end{tabular}




\begin{tabular}{|c|c|c|c|c|c|c|c|}
\hline \multicolumn{8}{|c|}{$\begin{array}{l}\text { TABLE } 9 \text { - IMPACT OF THE SIME/DIME NEGATIVE INCOME TAX EXPERIMENT ON HOURS WORKED } \\
\text { YEAR BY YEAR REGRESSIONS } \\
\text { WOMEN IN DUAL-HEADED HOUSEHOLDS }\end{array}$} \\
\hline \multicolumn{2}{|c|}{ Pre-Experiment } & Year 1 & Year 2 & Year 3 & Year 4 & Year 5 & Year 6 \\
\hline \multicolumn{8}{|c|}{ Households Receiving Job Training Treatment Only } \\
\hline Three-Year Program & $\begin{array}{c}6.9 \\
(65.9)\end{array}$ & $\begin{array}{l}-78.9 \\
(50.2)\end{array}$ & $\begin{array}{l}-106.8 \\
(60.8)\end{array}$ & $\begin{array}{l}-62.8 \\
(66.1)\end{array}$ & $\begin{array}{l}-113.7 \\
(69.6)\end{array}$ & $\begin{array}{c}-62.6 \\
(102.4)\end{array}$ & \\
\hline Five-Year Program & $\begin{array}{l}214.9 \\
(88.8)\end{array}$ & $\begin{array}{l}-12.8 \\
(67.7)\end{array}$ & $\begin{array}{l}-184.9 \\
(82.0)\end{array}$ & $\begin{array}{l}-185.6 \\
(89.1)\end{array}$ & $\begin{array}{l}-266.3 \\
(94.0)\end{array}$ & $\begin{array}{c}-55.7 \\
(106.7)\end{array}$ & $\begin{array}{l}-143.5 \\
(111.9)\end{array}$ \\
\hline $\begin{array}{l}\text { Five-Year - Three Year } \\
\text { T-test for Duration Differences }\end{array}$ & $\begin{array}{c}208.0 \\
2.10\end{array}$ & $\begin{array}{l}66.1 \\
0.88\end{array}$ & $\begin{array}{c}-78.1 \\
0.85\end{array}$ & $\begin{array}{l}-122.7 \\
1.23\end{array}$ & $\begin{array}{l}-152.6 \\
1.46\end{array}$ & $\begin{array}{c}6.9 \\
0.05\end{array}$ & \\
\hline \multicolumn{8}{|c|}{ Households Receiving NIT Treatment Only } \\
\hline Three-Year Program & $\begin{array}{l}-126.6 \\
(57.7)\end{array}$ & $\begin{array}{l}-74.9 \\
(44.0)\end{array}$ & $\begin{array}{l}-119.3 \\
(53.3)\end{array}$ & $\begin{array}{l}-116.9 \\
(58.0)\end{array}$ & $\begin{array}{l}-52.3 \\
(61.1)\end{array}$ & $\begin{array}{c}97.8 \\
(107.1)\end{array}$ & \\
\hline Five-Year Program & $\begin{array}{c}9.8 \\
(67.7)\end{array}$ & $\begin{array}{l}-38.5 \\
(51.6)\end{array}$ & $\begin{array}{l}-136.9 \\
(62.5)\end{array}$ & $\begin{array}{l}-142.0 \\
(67.9)\end{array}$ & $\begin{array}{l}-231.4 \\
(71.6)\end{array}$ & $\begin{array}{l}-217.5 \\
(85.0)\end{array}$ & $\begin{array}{l}-94.3 \\
(93.5)\end{array}$ \\
\hline $\begin{array}{l}\text { Five-Year - Three Year } \\
\text { T-test for Duration Differences }\end{array}$ & $\begin{array}{c}136.4 \\
1.93\end{array}$ & $\begin{array}{l}36.4 \\
0.68\end{array}$ & $\begin{array}{l}-17.6 \\
0.27\end{array}$ & $\begin{array}{c}-25.1 \\
0.35\end{array}$ & $\begin{array}{c}-179.1 \\
2.40\end{array}$ & $\begin{array}{l}-315.2 \\
2.73\end{array}$ & \\
\hline \multicolumn{8}{|c|}{ Households Receiving Both Job Training and NIT Treatments } \\
\hline Three-Year Program & $\begin{array}{l}-17.2 \\
(62.0)\end{array}$ & $\begin{array}{l}-77.2 \\
(47.3)\end{array}$ & $\begin{array}{l}-213.1 \\
(57.2)\end{array}$ & $\begin{array}{l}-181.3 \\
(62.2)\end{array}$ & $\begin{array}{l}-110.5 \\
(65.6)\end{array}$ & $\begin{array}{c}27.1 \\
(95.2)\end{array}$ & \\
\hline Five-Year Program & $\begin{array}{l}135.9 \\
(73.9)\end{array}$ & $\begin{array}{l}-142.7 \\
(56.3)\end{array}$ & $\begin{array}{c}-323.7 \\
(68.2)\end{array}$ & $\begin{array}{l}-272.3 \\
(74.2)\end{array}$ & $\begin{array}{l}-370.7 \\
(78.2)\end{array}$ & $\begin{array}{l}-208.3 \\
(92.7)\end{array}$ & $\begin{array}{c}-111.4 \\
(99.9)\end{array}$ \\
\hline Five-Year - Three Year & 153.1 & -65.5 & -110.6 & -91.0 & -260.2 & -235.4 & \\
\hline T-test for Duration Differences & 1.91 & 1.07 & 1.49 & 1.13 & 3.07 & 2.10 & \\
\hline
\end{tabular}




\begin{tabular}{|c|c|c|c|c|c|c|c|}
\hline \multicolumn{8}{|c|}{$\begin{array}{c}\text { TABLE } 10 \text { - IMPACT OF THE SIME/DIME NEGATIVE INCOME TAX EXPERIMENT ON HOURS WORKED } \\
\text { YEAR BY YEAR REGRESSIONS } \\
\text { WOMEN IN SINGLE-HEADED HOUSEHOLDS }\end{array}$} \\
\hline & Pre-Experiment & Year 1 & Year 2 & Year 3 & Year 4 & Year 5 & Year 6 \\
\hline \multicolumn{8}{|l|}{ A. Final Report Results } \\
\hline Three-Year Treatment & & $\begin{array}{l}-50 \\
(38.7)\end{array}$ & $\begin{array}{l}-134.1 \\
(45.7)\end{array}$ & $\begin{array}{l}-222.8 \\
(49.7)\end{array}$ & $\begin{array}{l}-96.7 \\
(52.0)\end{array}$ & $\begin{array}{l}-87.3 \\
(73.3)\end{array}$ & \\
\hline Five-Year Treatment & & $\begin{array}{c}-87 \\
(48.0)\end{array}$ & $\begin{array}{l}-170.4 \\
(56.6)\end{array}$ & $\begin{array}{l}-252.1 \\
(61.6)\end{array}$ & $\begin{array}{l}-340.9 \\
(64.4)\end{array}$ & $\begin{array}{l}-405.7 \\
(76.3)\end{array}$ & $\begin{array}{l}-170.1 \\
(94.4)\end{array}$ \\
\hline $\begin{array}{l}\text { Five-Year - Three Year } \\
\text { Treament Differential }\end{array}$ & & -37.0 & -36.3 & -29.3 & -244.2 & -318.4 & \\
\hline T-Test for Duration Differences & & 0.85 & 0.71 & 0.53 & 4.20 & 4.22 & \\
\hline $\mathrm{N}$ & & 1459 & 1459 & 1459 & 1459 & 951 & 458 \\
\hline \multicolumn{8}{|c|}{ B. Re-Analysis Using Final Report Specification } \\
\hline Three-Year Treatment & $\begin{array}{c}43.1 \\
(41.4)\end{array}$ & $\begin{array}{l}-55.8 \\
(39.0)\end{array}$ & $\begin{array}{l}-142.0 \\
(45.9)\end{array}$ & $\begin{array}{l}-231.9 \\
(49.9)\end{array}$ & $\begin{array}{l}-82.5 \\
(52.5)\end{array}$ & $\begin{array}{l}-124.3 \\
(74.2)\end{array}$ & \\
\hline Five-Year Treatment & $\begin{array}{l}115.9 \\
(51.4)\end{array}$ & $\begin{array}{l}-61.1 \\
(48.4)\end{array}$ & $\begin{array}{l}-152.0 \\
(57.1)\end{array}$ & $\begin{array}{l}-228.4 \\
(62.0)\end{array}$ & $\begin{array}{l}-335.3 \\
(65.3)\end{array}$ & $\begin{array}{l}-414.7 \\
(77.1)\end{array}$ & $\begin{array}{l}-197.1 \\
(94.0)\end{array}$ \\
\hline $\begin{array}{l}\text { Five-Year - Three Year } \\
\text { Treament Differential }\end{array}$ & 72.8 & -5.4 & -10.0 & 3.5 & -252.8 & -290.4 & \\
\hline T-Test for Duration Differences & 1.55 & 0.12 & 0.19 & 0.06 & 4.25 & 3.79 & \\
\hline $\mathrm{N}$ & 1433 & 1433 & 1433 & 1433 & 1433 & 945 & 458 \\
\hline
\end{tabular}




\begin{tabular}{|c|c|c|c|c|c|c|}
\hline \multicolumn{7}{|c|}{$\begin{array}{l}\text { APPENDIX TABLE } 1 \text { - IMPACT OF THE SIME/DIME JOB TRAINING EXPERIMENT ON HOURS WORKED } \\
\text { FINAL REPORT RESULTS } \\
\text { MEN IN DUAL-HEADED HOUSEHOLDS }\end{array}$} \\
\hline & Year 1 & Year 2 & Year 3 & Year 4 & Year 5 & Year 6 \\
\hline \multicolumn{7}{|l|}{ Counseling Only: } \\
\hline Three-Year Treatment & $\begin{array}{c}-3 \\
(37.8)\end{array}$ & $\begin{array}{c}34.9 \\
(49.6)\end{array}$ & $\begin{array}{c}33.1 \\
(57.2)\end{array}$ & $\begin{array}{c}24.1 \\
(61.8)\end{array}$ & $\begin{array}{l}-52.5 \\
(99.6)\end{array}$ & \\
\hline Five-Year Treatment & $\begin{array}{c}-2.8 \\
(47.1)\end{array}$ & $\begin{array}{c}32 \\
(60.9)\end{array}$ & $\begin{array}{l}-115.3 \\
(70.5)\end{array}$ & $\begin{array}{l}-80.6 \\
(76.6)\end{array}$ & $\begin{array}{c}12.8 \\
(83.9)\end{array}$ & $\begin{array}{c}-115.6 \\
(87.1)\end{array}$ \\
\hline Five-Year - Three-Year Impact & 0.2 & -2.9 & -148.4 & -104.7 & 65.3 & \\
\hline \multicolumn{7}{|l|}{ Counseling Plus 50 Percent Subsidy: } \\
\hline Three-Year Treatment & $\begin{array}{l}-71.7 \\
(33.6)\end{array}$ & $\begin{array}{c}37.9 \\
(44.4)\end{array}$ & $\begin{array}{c}62.6 \\
(49.7)\end{array}$ & $\begin{array}{c}22.4 \\
(54.2)\end{array}$ & $\begin{array}{l}-16.9 \\
(75.3)\end{array}$ & \\
\hline Five-Year Treatment & $\begin{array}{l}-105.6 \\
(41.9)\end{array}$ & $\begin{array}{l}-94.2 \\
(54.1)\end{array}$ & $\begin{array}{l}-36.7 \\
(59.4)\end{array}$ & $\begin{array}{l}-73.7 \\
(64.5)\end{array}$ & $\begin{array}{l}-45.3 \\
(70.5)\end{array}$ & $\begin{array}{l}-18.7 \\
(73.7)\end{array}$ \\
\hline Five-Year - Three-Year Impact & -33.9 & -132.1 & -99.3 & -96.1 & -28.4 & \\
\hline \multicolumn{7}{|l|}{ Counseling Plus 100 Percent Subsidy: } \\
\hline Three-Year Treatment Only & $\begin{array}{l}-88.8 \\
(33.9)\end{array}$ & $\begin{array}{l}-40.3 \\
(44.3)\end{array}$ & $\begin{array}{c}-52.7 \\
(49.6)\end{array}$ & $\begin{array}{c}-37.9 \\
(53.8)\end{array}$ & $\begin{array}{c}-43.7 \\
(75.0)\end{array}$ & \\
\hline
\end{tabular}




\begin{tabular}{|c|c|c|c|c|c|c|}
\hline \multicolumn{7}{|c|}{$\begin{array}{c}\text { APPENDIX TABLE } 2 \text { - IMPACT OF THE SIME/DIME JOB TRAINING EXPERIMENT ON HOURS WORKED } \\
\text { FINAL REPORT RESULTS } \\
\text { WOMEN IN DUAL-HEADED HOUSEHOLDS }\end{array}$} \\
\hline & Year 1 & Year 2 & Year 3 & Year 4 & Year 5 & Year 6 \\
\hline \multicolumn{7}{|l|}{ Counseling Only: } \\
\hline Three-Year Treatment & $\begin{array}{c}-8.6 \\
(34.3)\end{array}$ & $\begin{array}{c}-28.6 \\
(46.3)\end{array}$ & $\begin{array}{l}-24.3 \\
(54.0)\end{array}$ & $\begin{array}{l}-61.8 \\
(57.8)\end{array}$ & $\begin{array}{l}-65.3 \\
(96.3)\end{array}$ & \\
\hline Five-Year Treatment & $\begin{array}{l}-77.1 \\
(42.6)\end{array}$ & $\begin{array}{c}-164 \\
(56.7)\end{array}$ & $\begin{array}{r}-163.9 \\
(66.9)\end{array}$ & $\begin{array}{l}-197.9 \\
(71.2)\end{array}$ & $\begin{array}{l}-68.4 \\
(82.9)\end{array}$ & $\begin{array}{l}-125.8 \\
(86.2)\end{array}$ \\
\hline Five-Year - Three-Year Impact & -68.5 & -135.4 & -139.6 & -136.1 & -3.1 & \\
\hline \multicolumn{7}{|l|}{ Counseling Plus 50 Percent Subsidy: } \\
\hline Three-Year Treatment & $\begin{array}{l}-14.9 \\
(30.5)\end{array}$ & $\begin{array}{l}-25.3 \\
(41.1)\end{array}$ & $\begin{array}{c}-5.1 \\
(47.2)\end{array}$ & $\begin{array}{l}-63.9 \\
(50.9)\end{array}$ & $\begin{array}{c}-6.2 \\
(77.4)\end{array}$ & \\
\hline Five-Year Treatment & $\begin{array}{l}-107.8 \\
(38.5)\end{array}$ & $\begin{array}{c}-109.8 \\
(51.0)\end{array}$ & $\begin{array}{l}-83.2 \\
(57.8)\end{array}$ & $\begin{array}{l}-43.1 \\
(61.8)\end{array}$ & $\begin{array}{l}-44.1 \\
(71.7)\end{array}$ & $\begin{array}{l}-52.1 \\
(75.1)\end{array}$ \\
\hline Five-Year - Three-Year Impact & -92.9 & -84.5 & -78.1 & 20.8 & -37.9 & \\
\hline \multicolumn{7}{|c|}{ Counseling Plus 100 Percent Subsidy: } \\
\hline Three-Year Treatment Only & $\begin{array}{c}-10 \\
(30.9)\end{array}$ & $\begin{array}{l}-71.1 \\
(41.5)\end{array}$ & $\begin{array}{c}6.3 \\
(47.6)\end{array}$ & $\begin{array}{l}-96.1 \\
(51.5)\end{array}$ & $\begin{array}{c}-64.4 \\
(76.1)\end{array}$ & \\
\hline
\end{tabular}



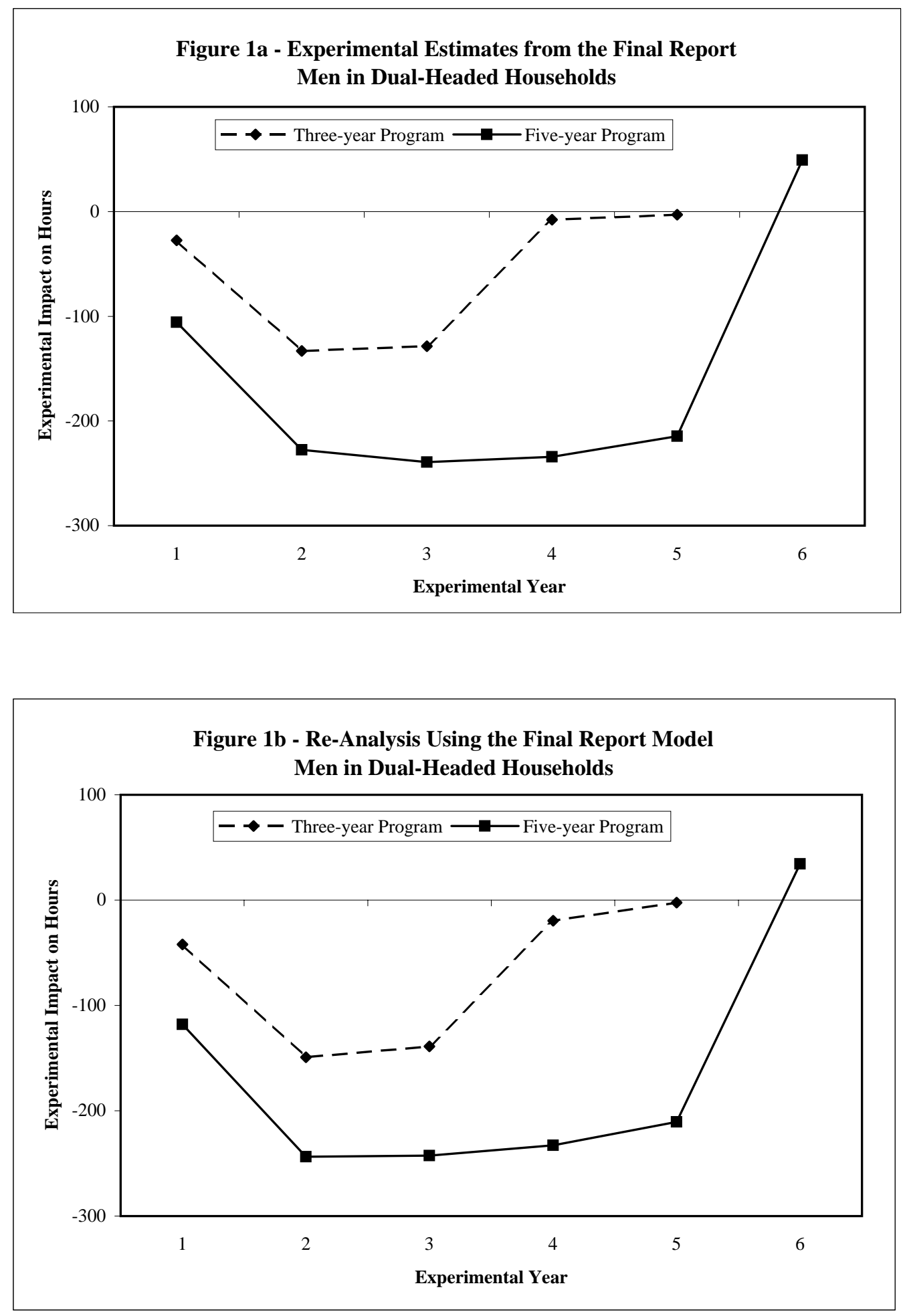

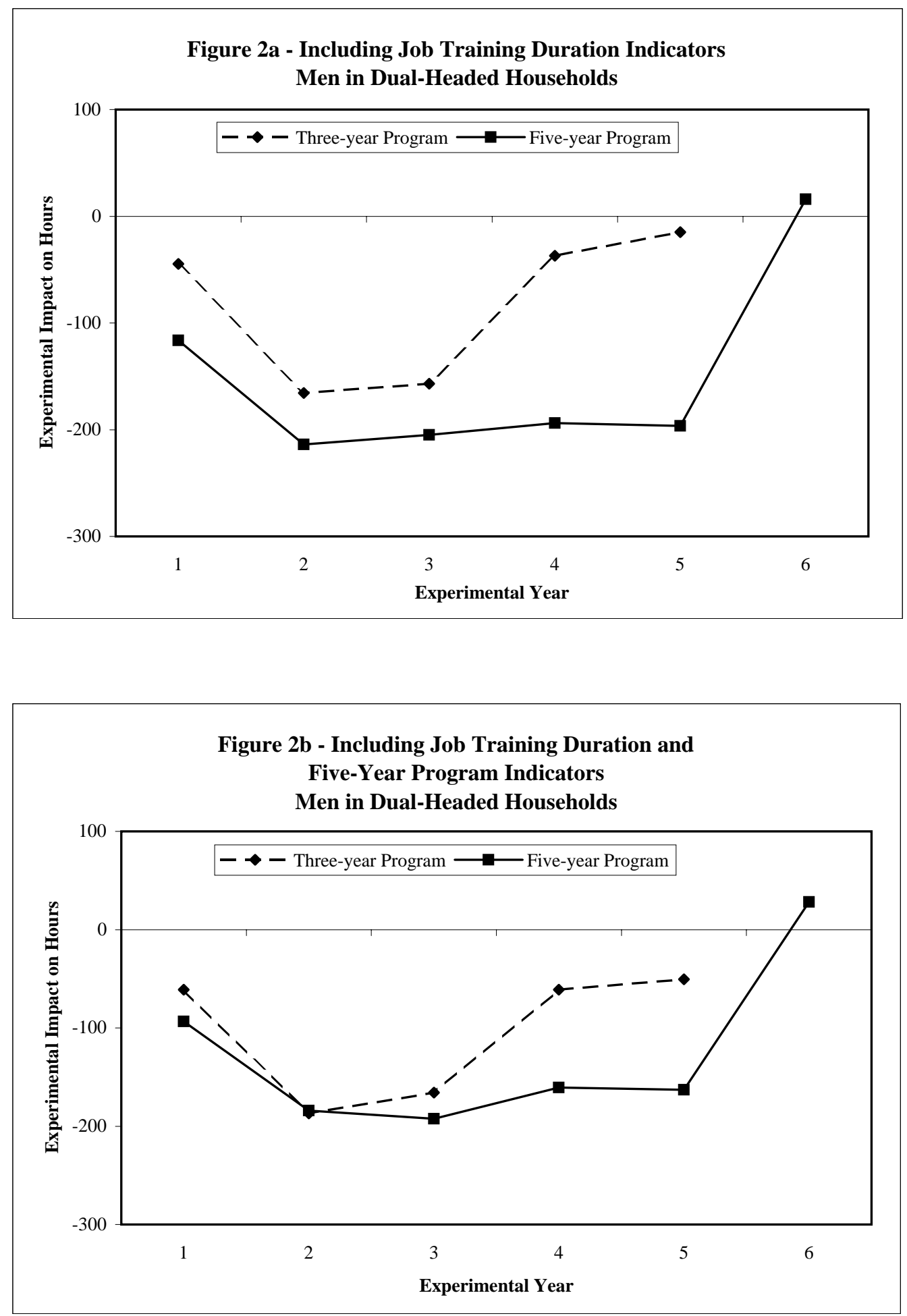


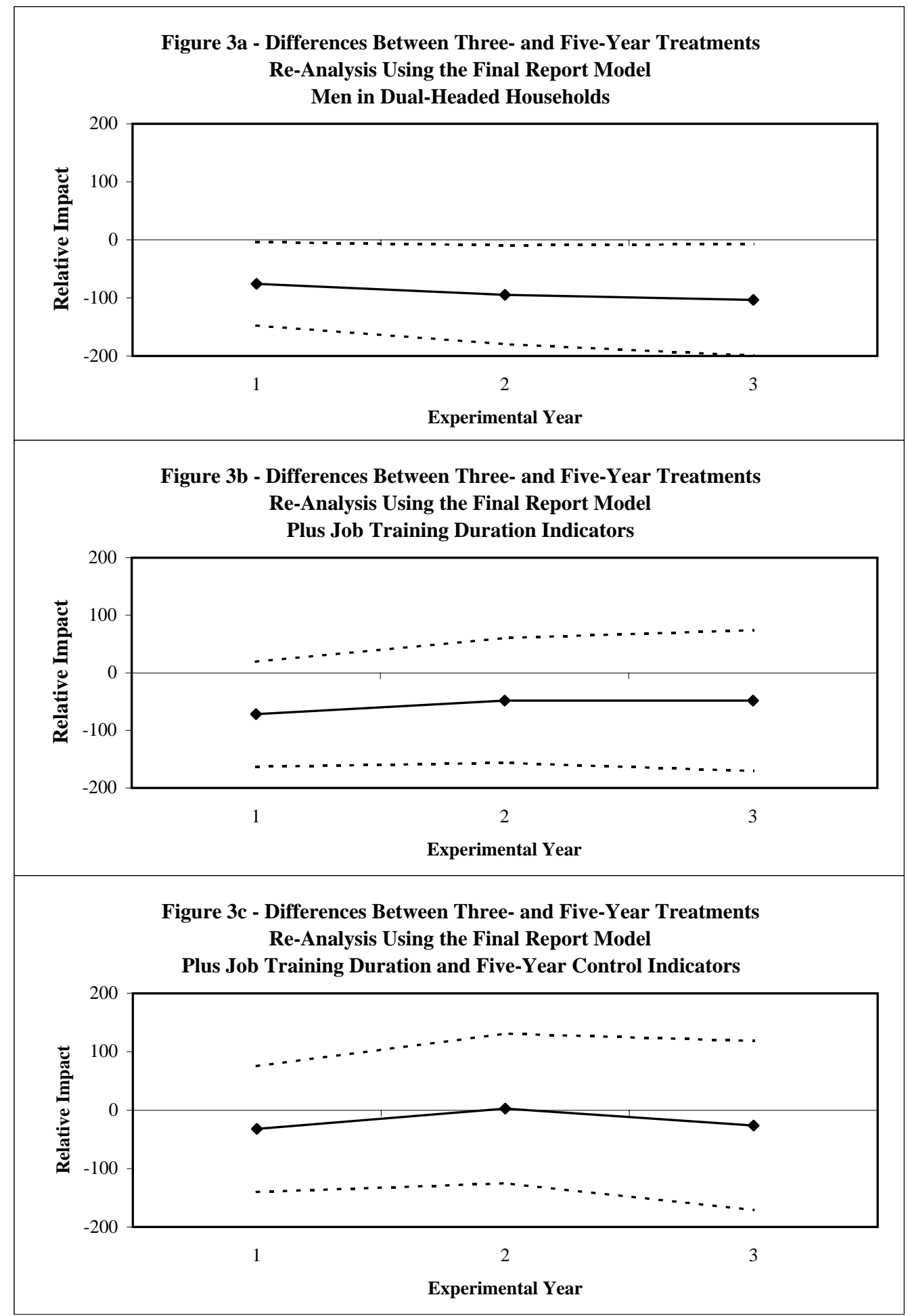



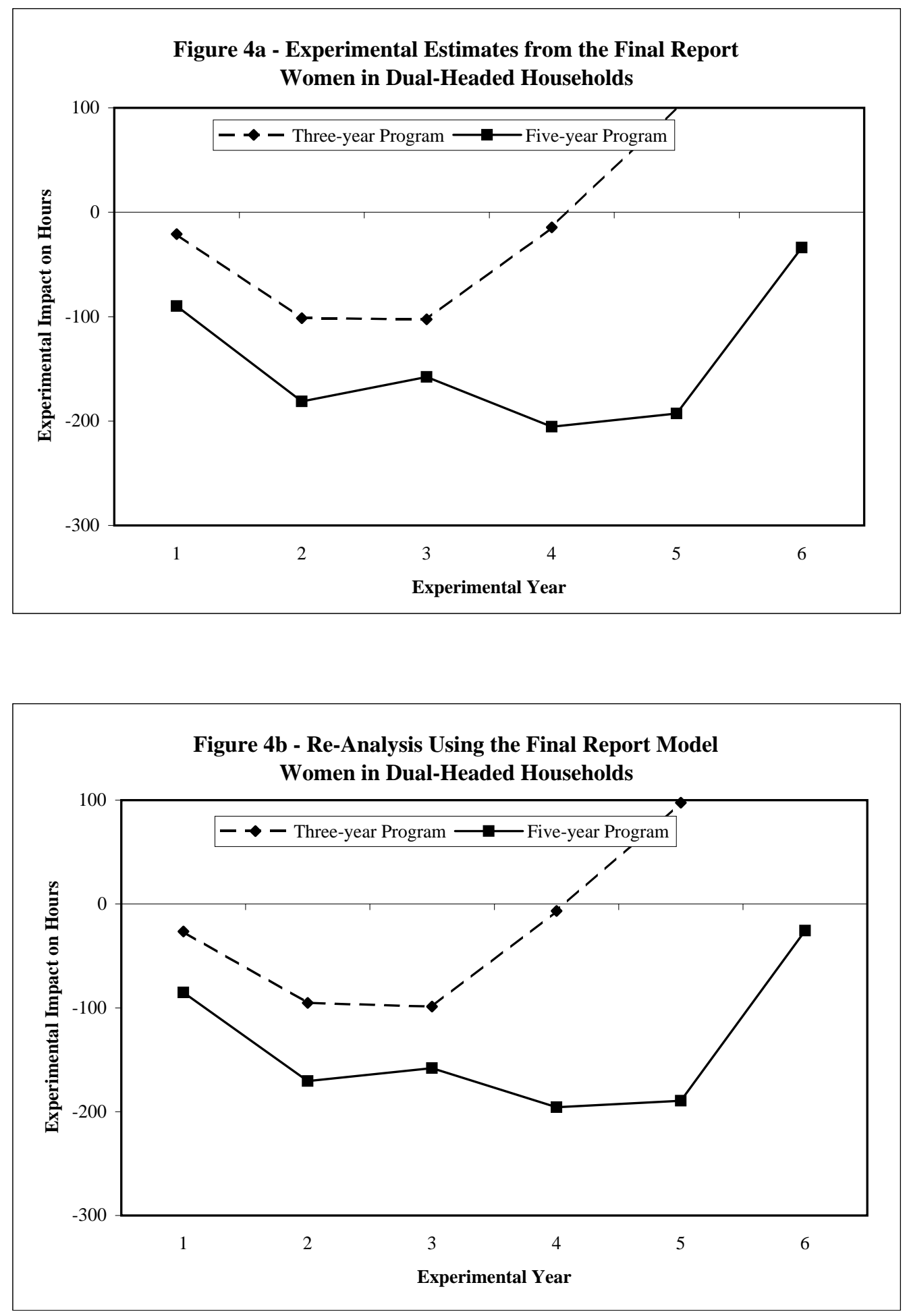

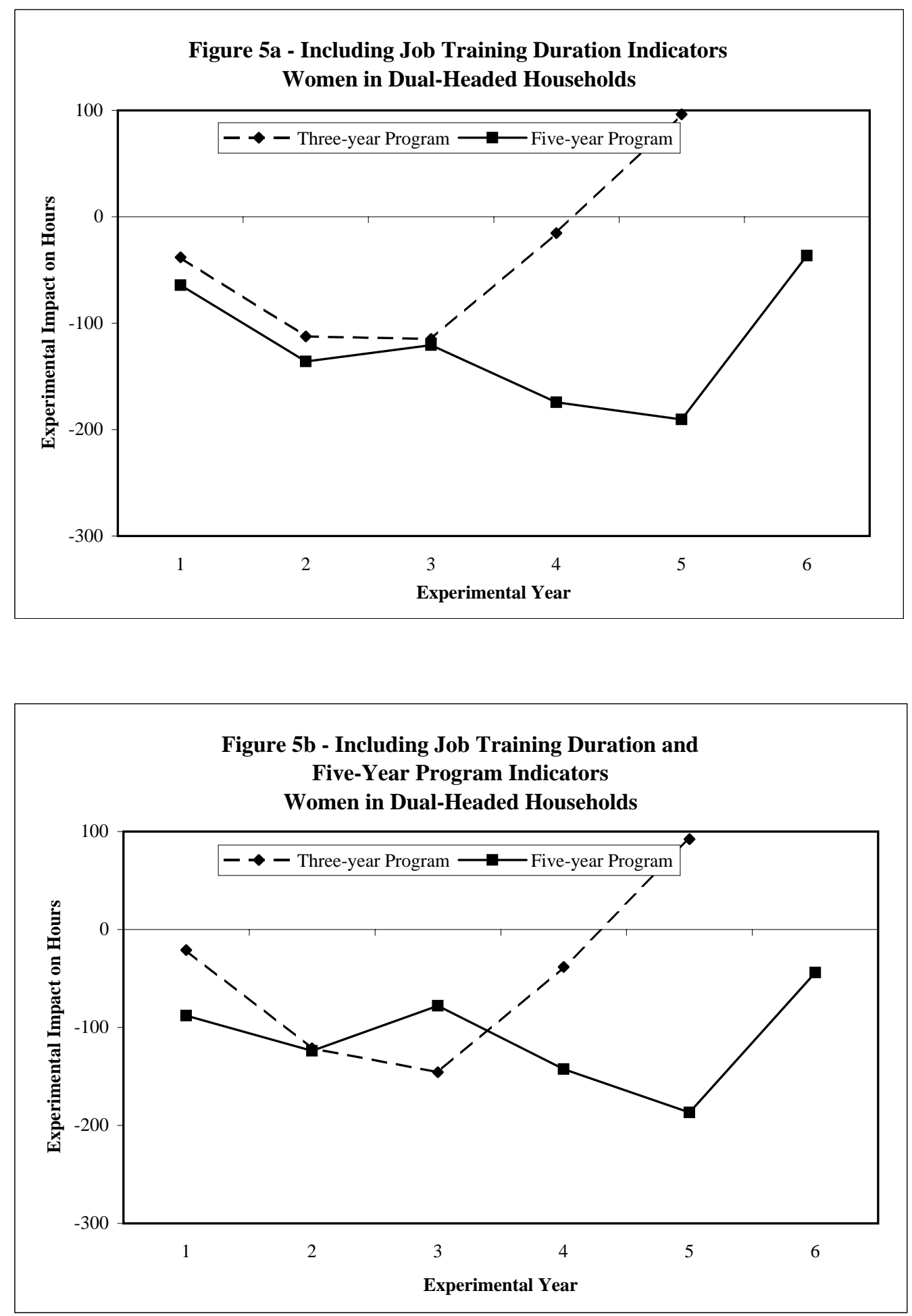


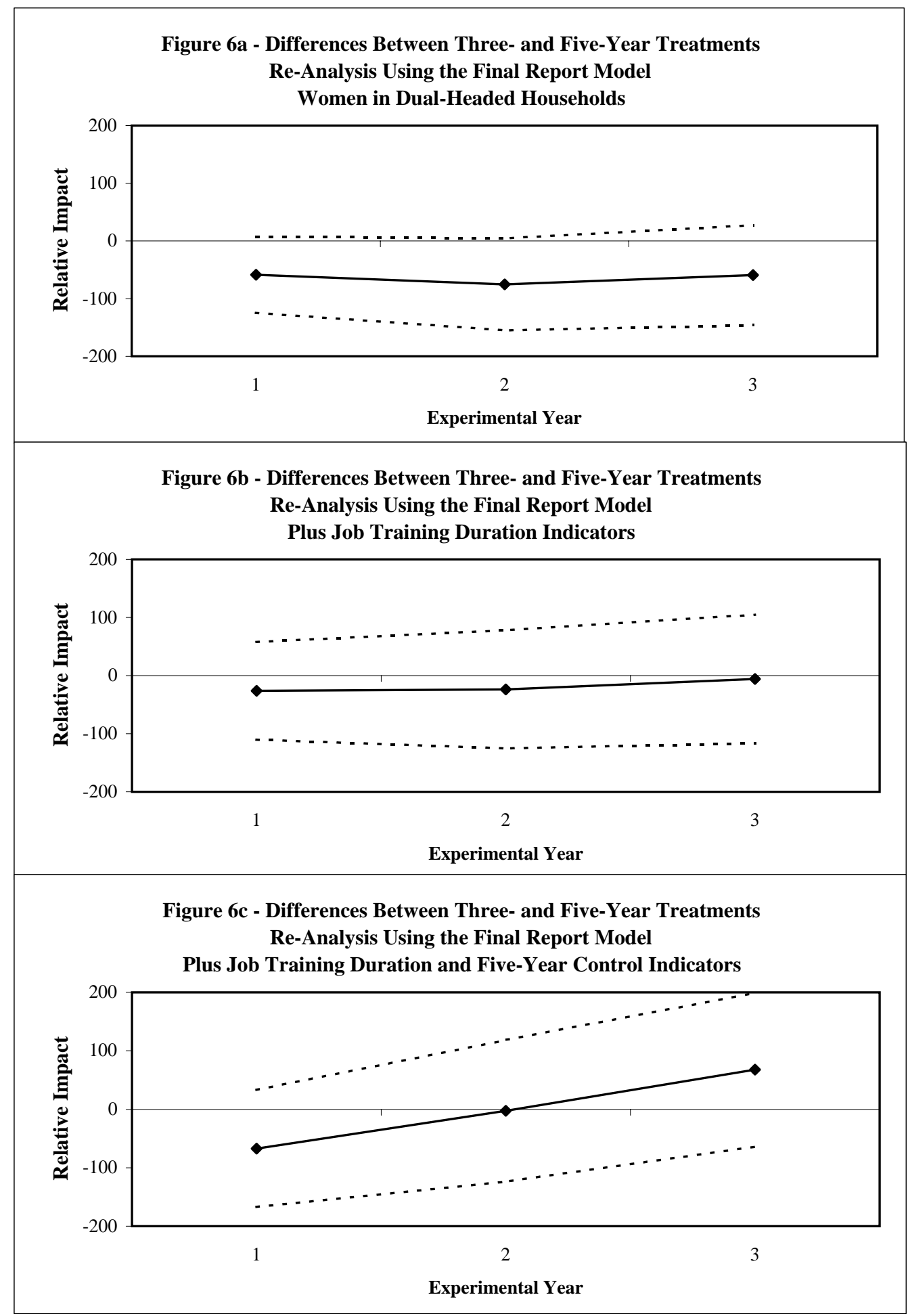

